\title{
BIENES FUNERARIOS DEL CEMENTERIO CHINCHORRO MORRO 1: DESCRIPCIÓN, ANÁLISIS E INTERPRETACIÓN
}

\author{
FUNERARY GOODS FROM CHINCHORRO MORRO I CEMETERY: \\ DESCRIPTION, ANALYSIS AND INTERPRETATION
}

\author{
Vivien G. Standen*
}

\begin{abstract}
En este trabajo se describen los contextos funerarios asociados a 134 individuos del cementerio chinchorro Morro 1 (5.400-3.700 a.p.), localizado en el extremo norte de Chile. Se identificaron 301 bienes funerarios, los cuales muestran una clara tendencia a ser depositados con mayor frecuencia entre los individuos con momificación natural ( $\mathrm{n}=184 / 2,3$ especímenes por individuo) y los tratados con pátina de arena $(n=39 / 2,1$ especímenes por individuo). En contraste, los individuos con momificación artificial muestran una menor cantidad y variedad de bienes asociados $(n=23 / 0,6$ especímenes por individuo). Se encontraron además 55 registros culturales ubicados en sectores disturbados, sin asociación a cuerpos específicos.

Los bienes funerarios corresponden a: (1) vestimenta y adornos corporales (faldellines, cobertores púbicos, collares, cintillos y gorros); (2) instrumentos para la explotación de los recursos marinos: de caza (cabezales, barbas y astiles de arpón), de pesca (anzuelos y sedales de fibra vegetal, y pesas líticas), de recolección (chopes o desconchadores de hueso y bolsas redes); (3) instrumentos relacionados con las actividades de caza terrestre (estólicas, lanzas y dardos); (4) material misceláneo: bolsitas de cuero, cubiletes y punzones de hueso, brochas y esteras vegetales, cestería, aguja, alfileres, limas, pieles de camélido, ave y lobo marino. Aquellos bienes vinculados con las prácticas de caza son significativamente más frecuentes que los de pesca y recolección. Las mujeres están asociadas con más implementos de pesca (anzuelos, pesas y sedales) mientras los hombres se asocian con más implementos de caza (astiles y barbas para arpones). Esta distribución de los bienes funerarios parece reflejar un cierto orden social respecto a los roles sexuales al interior de la sociedad chinchorro. Finalmente se discuten aspectos más generales relacionados con la cronología del sitio, intercambio con cazadores andinos, dieta, subsistencia y orígenes de las poblaciones arcaicas.

Palabras claves: Tradición chinchorro, contextos funerarios, diferenciación sexual, vestimenta, actividades económicas e intercambio.
\end{abstract}

In this paper we describe the funerary contexts associated to 134 individuals from the Chinchorro cemetery Morro 1 (5,400-3,700 a.p.), in northernmost Chile. We identified 301 funerary goods, with those individuals with natural mummification showing the higher number and variety of objects $(n=184 / 2,3$ objects per individual), followed by individuals with a sand cover $(n=39 / 2,1$ objects per individual) and finally those with artificial mummification $(n=23 / 0,6$ objects per individual). In addition we found 55 cultural records of objects in disturbed areas without association to a particular individual.

The funerary objects correspond to: (1) clothing and body ornaments; (2) tools associated to the exploitation of marine resources: for hunting, fishing, and gathering; (3) tools associated to hunting of terrestrial resources; (4) miscellaneous material such as leather bags, and skins of camelids, birds and see mammals.

Those objects associated to hunting activities are significantly more frequent than those associated to fishing and gathering of resources. Women are associated to fishing tools while men are associated to hunting tools. This patterned distribution of funerary objects seems to reflect a social order linked to the existence of different sexual roles in the Chinchorro society. Finally, we discuss general aspects associated to the chronology of the site, exchange activities with Andean hunters, diet, subsistence, and origin of archaic populations.

Key words: Chinchorro tradition, funerary context, sexual differentiation, clothing, economic activities, exchange.

Uno de los aspectos más relevantes de los pueblos de cazadores y pescadores arcaicos (9.0003.700 a.p.) del desierto costero del norte de Chile y sur de Perú lo constituyen sus prácticas funerarias, que consistían, entre otras, en un sofisticado procedimiento para preservar y mantener a sus difuntos (Allison et al. 1984; Alvarez 1969; Arriaza
1994, 1995; Aufderheide et al. 1993; Bittman 1982; Bittman y Munizaga 1976, 1979; Guillén 1992; Llagostera 1989; Munizaga 1974; Muñoz et al. 1993; Núñez 1969; Rivera 1975; Rivera y Rothhammer 1986, 1991; Schiappacasse y Niemeyer 1984; Soto 1987; Standen 1991, 1997; Uhle 1917, 1919; Wise 1995, entre otros). Sin embargo, existe

* Centro de Investigaciones del Hombre en el Desierto, Departamento de Arqueología y Museología, Facultad de Ciencias Sociales, Administrativas y Económicas, Universidad de Tarapacá. Casilla 6-D, Arica, Chile. vstanden@uta.cl. 
un déficit de información respecto de los contextos culturales asociados a los distintos tipos de tratamiento mortuorio que se desarrollaron a través de 5.000 años. Otro de los aspectos no precisados es el problema cronológico del desarrollo de esta tradición cultural. Esto se debe, en parte, a que no se ha establecido una clara correlación entre lo llamado "Chinchorro", con las adaptaciones tempranas de tradición marítima, llámense "Cultura del Anzuelo de Concha", "Cultura del Anzuelo de Quisco", "Cultura Chinchorro", "Tradición Chinchorro", "Complejo Tiliviche", "Complejo Camarones" o "Complejo Quiani", etc. (Arriaza 1995; Bird 1943, 1946; Llagostera 1989; Núñez 1983, 1999; Rivera y Rothhammer 1986, 1991; Wise 1995). En general, existe la tendencia a interpretar a chinchorro sólo como la expresión funeraria de la secuencia tardía del Período Arcaico, entre los 5.000 a 4.000 a.p. (Llagostera 1989; Núñez 1983, 1999). Sin embargo, los nuevos antecedentes para este período han demostrado que los indicadores tecnológicos y culturales propuestos para sustentar dichas divisiones cronológicas resultan algo arbitrarios y tienden a mostrar más bien una continuidad temporal. Asimismo, la tecnología, la economía, las prácticas mortuorias, la dieta y las industrias líticas, muestran rasgos conservadores a través de toda la secuencia arcaica, lo cual parece indicar una continuidad poblacional, tanto en la costa como en los oasis interiores, sustentada también por la evidencia biológica (Cocilovo et al. 2001; Rothhammer 1989; Sutter 1997).

Las excavaciones en el sitio Morro 1 (Figura 1) han generado información sobre las prácticas funerarias y nuevas propuestas interpretativas (Allison et al. 1984; Arriaza 1994, 1995; Rivera y Rothhammer 1986, 1991; Standen 1991, 1997). En este trabajo, se presenta la información correspondiente sólo a los contextos culturales asociados a 134 individuos excavados del sitio Morro 1.

\section{El Sitio Morro 1}

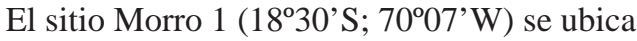
en la costa del extremo norte de Chile, sobre la ladera norte de una formación rocosa cubierta de dunas. Corresponde al último remanente de la cordillera de la Costa, antes de sumergirse en las aguas del Pacífico. Este promontorio natural, conocido como "Morro de Arica", fue uno de los lugares escogido por los antiguos pueblos costeros para depositar a sus difuntos. Se trata de un espacio de jerarquía, con una vista hacia el mar y la desembocadura de los valles de Azapa y Lluta.

El área funeraria está inserta en la trama urbana de la ciudad (Figura 1), por lo que el sitio ha quedado obliterado con construcciones y tránsito vehicular, razón por la cual la zona es altamente sensible a la intervención de personas ajenas a la labor científica. Parte de la colección "Aborígenes de Arica" proviene del mismo lugar, donde Uhle (1919) excavó más de un centenar de individuos, que le sirvieron de base para proponer su clásica tipología de momias. Posteriormente, Munizaga y Martínez (1961) describen una estólica y una figurina de arcilla encontradas en el mismo talud del cerro. En 1984 se realizó la excavación de rescate del sitio Morro 1 (Allison et al. 1984; Standen 1991) registrándose 96 individuos $^{1}$; Focacci (1989) lleva a cabo otra excavación, y rescata 60 individuos, ubicados a $30 \mathrm{~m}$ hacia el este de Morro 1, y que rotuló como Morro 1/6. En el sector de la Virgen rescata otros 20 individuos con momificación artificial (Morro 1/5), analizados y publicados por Guillén (1992). En 1990 se llevó a cabo otro rescate en el Consulado Peruano, donde se excavaron cinco individuos, todos del patrón arcaico. Por los patrones funerarios, contextos culturales, ubicación geográfica y los fechados de radiocarbono 14 , los sitios publicados como: Morro 1, Morro 1/6 y Morro 1/5 (Figura 1) y la colección "Aborígenes de Arica" de Uhle (1919) son parte de un mismo sustrato poblacional.

En el sitio Morro 1, se identificaron los tres patrones funerarios ya conocidos para esta tradición: (a) individuos con momificación artificial, en sus estilos negro y rojo (este último agrupa a un conjunto más diverso de técnicas); (b) individuos recubiertos con una pátina de arena, y (c) individuos con momificación natural (Allison et al. 1984; Arriaza 1994, 1995; Standen 1991, 1997).

\section{Cronología}

El cementerio Morro 1 fue usado durante ca.1700 años ${ }^{2}$ (Tabla 1). Se definieron tres fases, para entender el tiempo de ocupación del sitio: Fase I (temprana), II (media) y III (tardía) ${ }^{3}$, sustentadas en las dataciones de radiocarbono 14 , los contextos asociados, el patrón mortuorio y las técnicas de tratamiento de los cuerpos.

Fase I (ca. 5.500-5.000 a.p.). Los bienes funerarios presentes en esta fase son: (a) estólica de sec- 


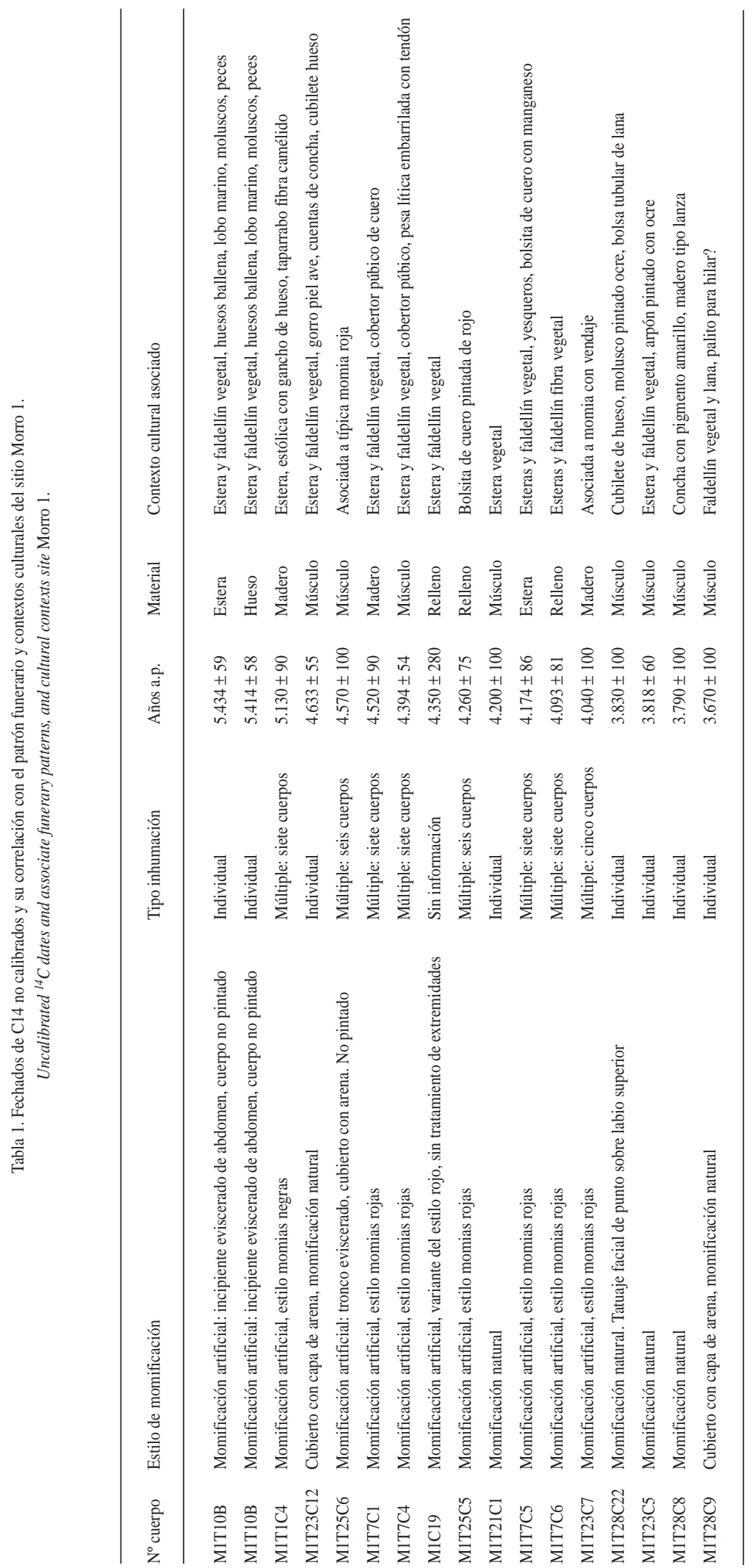




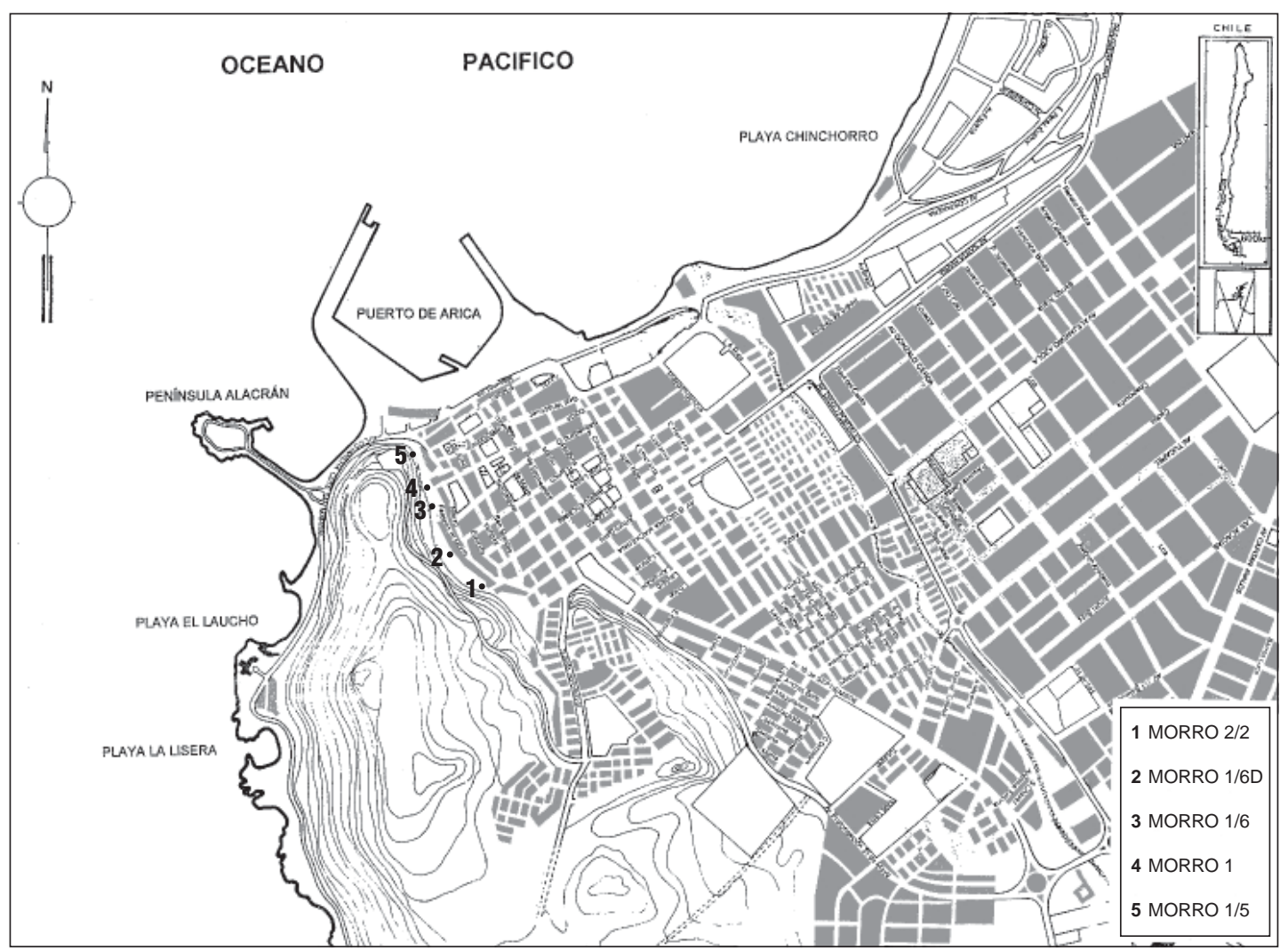

Figura 1. Ubicación sitios funerarios Chinchorro (Morro 1/5, Morro 1 y Morro 1/6), y Faldas del Morro (Morro 1/6D y Morro 2/2). Location of Chinchorro funerary sites (Morro 1/5, Morro 1, Morro 1/6) and Faldas del Morro (Morro 1/6D and Morro 2/2).

ción circular con gancho de hueso decorado con incisiones lineales; (b) fragmento de una punta de proyectil de cuarzo, del patrón lanceolado de talla bifacial; (c) esteras elaboradas en técnica de twining formando parte del tratamiento interno de los cuerpos, así como de la envoltura externa; (d) faldellín de fibra vegetal y taparrabo de fibra de camélido, y (e) pieles de camélido y lobo marino.

El patrón mortuorio se caracteriza por (a) una inhumación individual (M1T10B) que muestra sólo una evisceración parcial en la cavidad abdominal, con evidencias de haber sido expuesto al fuego, y (b) una inhumación múltiple de momias del estilo negro (M1T1). La datación más temprana es de $5.434 \pm 59$ a.p. que fecha la inhumación individual (M1T10B) 2 Comonota con un tratamiento simple, lejos de tener la complejidad de las momias negras. Sin embargo, tiene un elaborado contexto funerario (fardo de piel de lobo marino y esteras, cubierto con costillas y escápulas de lobo marino y ballena, conchas y restos de peces). En un mismo nivel, y a $2 \mathrm{~m}$ hacia el oeste, se excavó la inhu- mación múltiple (M1T1) de siete individuos (Standen 1997: Figura 2), datada en $5.130 \pm 90$ a.p. Muestran una técnica de momificación homogénea entre sí (estilo negro), la cual reflejaría una suerte de identidad entre los individuos que fueron inhumados juntos, uno adosado al otro, estando los infantes inmediatamente sobre los adultos. Dispusieron un par de costillas de ballena en el contorno de la inhumación. Este contexto funerario reflejaría lazos de parentesco cercano entre los individuos que conforman el entierro colectivo.

La presencia de la inhumación individual con un incipiente eviscerado y la inhumación múltiple de momias negras con un complejo tratamiento demuestra que están operando mecanismos selectivos en torno a los ritos mortuorios. Mientras a ciertos individuos, de ambos sexos y todas las edades, le practican un tratamiento complejo, donde son transformados en algo similar a una "escultura" y se entierran en forma colectiva, a otros, en este caso a una mujer, la depositan aisladamente y le practican sólo un eviscerado abdominal, pero con un elabo- 

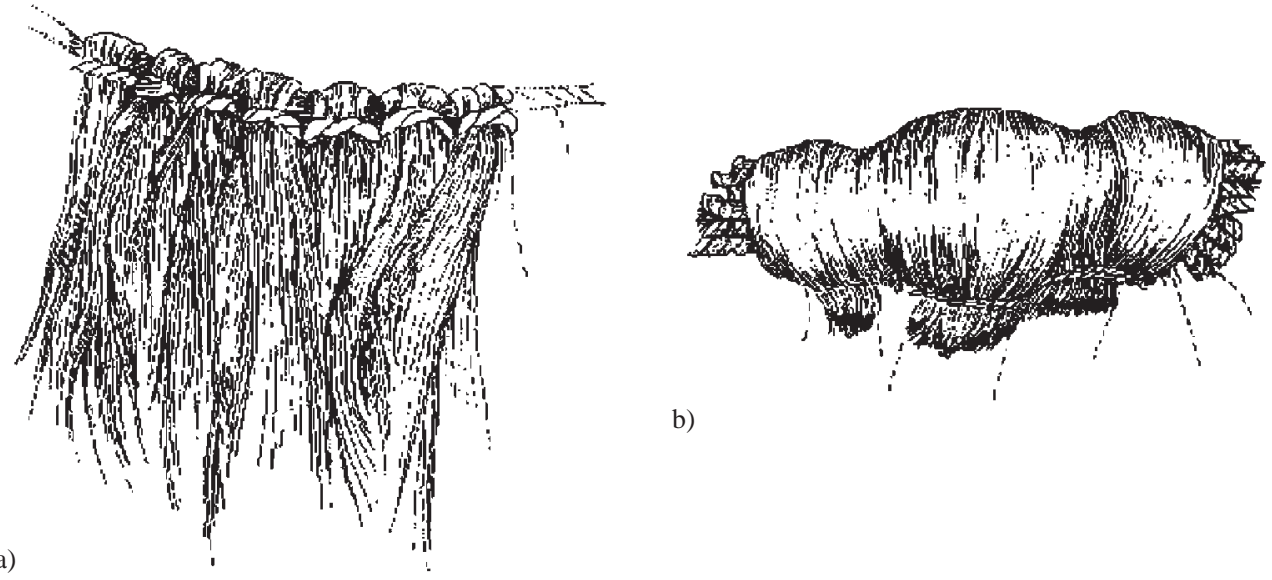

b)

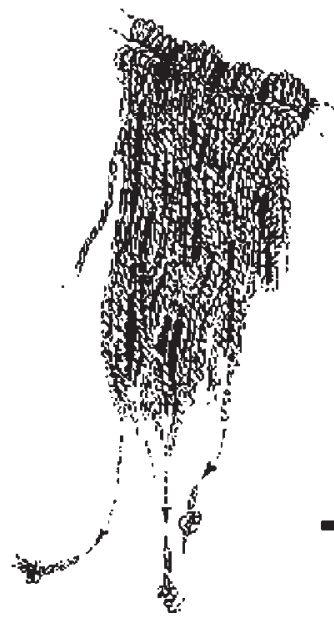

c)

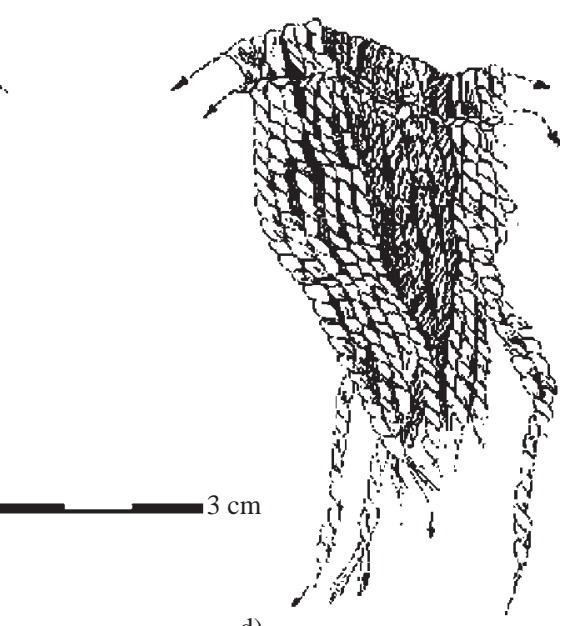

d)

Figura 2. Faldellines de fibra vegetal: (a y b) con pabilos no torcidos; ( $\mathrm{y}$ y d) con pabilos torcidos y nudos en los extremos terminales.

Skirts of vegetal fiber: $(a$ and $b$ ) unspun fiber; $(c$ and $d)$ spun fibers with knotted ends.

rado contexto funerario. ¿Sería esta mujer foránea al grupo, y provendría de otra zona costera?

Entre los ca. 5.000 y 4.600 a.p. hay un hiato cronológico, que parece ser concordante con un cambio sustancial en las técnicas de momificación, las "momias negras" desaparecen tanto del sitio Morro 1 como del resto de los cementerios chinchorros de Arica y Camarones, emergiendo un nuevo estilo, rotulado por Arriaza (1995) como "momias rojas".
Fase II (ca. 4.600-4.000 a.p.). Durante esta fase, la presencia de bienes funerarios aumenta levemente con relación a la fase anterior: cabezales, astiles y barbas de arpones, pesas líticas, brochas vegetales, bolsitas de fibra vegetal y de cuero para almacenar pigmentos. Por otro lado, continúan usando el mismo tipo de vestimenta que la fase anterior: faldellines (Figura 2) y cobertores púbicos, e incorporan el uso de cintillos cefálicos, collares y pendientes de concha. Se observan cambios sustanciales en el pa- 
trón mortuorio, ya que hay un reemplazo de las momias negras por las momias rojas. Este estilo no es realizado en forma tan uniforme como las negras, donde al parecer cierto grupo tenía el conocimiento de las técnicas y el procedimiento del tratamiento, el cual debió heredarse generación tras generación. En las momias rojas, se observa una mayor libertad en la elaboración, hay cuerpos que fueron eviscerados y descarnados, otros solo muestran evisceración parcial; las extremidades pueden o no ser tratadas, otros muestran la reposición de la piel a modo de un vendaje, disponen maderos en forma interna y/o externa al cuerpo. En el relleno también se observan variaciones: pieles de camélidos, haces de fibra vegetal, hojas de sorona macerada, tierra de colores como óxido de fierro y manganeso, material orgánico carbonoso (Allison et al. 1984; Arrriaza 1995; Standen 1997).

Además de las momias rojas, se registran los cuerpos con pátina de arena y los con momificación natural. Estos últimos constituyen mayoritariamente inhumaciones individuales y primarias, $\mathrm{y}$ forman agrupaciones no deliberadas, con ciertas excepciones, ya que identificamos una inhumación múltiple de seis individuos con momificación natural. En general son envueltos con pieles de camélido y minoritariamente pieles de ave y lobo marino, y sobre éstas colocan esteras vegetales. Mantienen la posición de enterramiento decúbito dorsal extendida, aunque sin el ordenamiento espacial observado en los individuos con momificación artificial, si no más bien los colocan superpuestos unos sobre otros, ya que no son tumbas. Tampoco hay elementos demarcatorios, por lo que al inhumar a un individuo pasaban a alterar otro enterrado en un tiempo anterior. Esta sería la razón por la cual los cuerpos muestran una gran erosión.

En general, durante esta fase se encuentra una mayor variabilidad en las prácticas mortuorias y una diversidad de nuevos estilos de momificación. La asociación entre individuos con momificación artificial (estilo rojo), con pátina de arena y con momificación natural, demostraría la contemporaneidad de los distintos patrones funerarios, por lo que los mecanismos selectivos en el tratamiento se hacen aún más evidentes (Standen 1997).

Fase III (ca. 4.000-3.600 a.p.). El cementerio se continúa usando con fines funerarios, se advierte un aumento en disposición de bienes asociados a los individuos, concordante con la disolución de la momificación artificial. Durante esta fase predominan los individuos con momificación natural y los con pátina de arena. Los bienes siguen siendo mayoritariamente artefactos vinculados con la explotación de los recursos marinos, más algunos restos orgánicos.

Sin embargo, se observan varios rasgos innovadores: (a) la práctica de disponer bienes funerarios aumenta; (b) la deformación cefálica intencional, tipo circular oblicua se hace más popular; (c) un tatuaje facial, de hileras de punto, sobre el labio superior de un hombre adulto (M1T28C22); (d) dos casos de tapones nasales de fibra vegetal; (e) la práctica de entrelazar los dedos de las manos y los pies con una cuerda de fibra vegetal y/o camélido (hilada y torcida) a modo de una trama, probablemente con fines rituales, se hace característico. Por otro lado, se observan un conjunto de rasgos que persisten durante las tres fases definidas, lo que demuestra la continuidad de la población (Tabla 2), y que corresponden a: (a) la momificación artificial, aunque cambia el estilo, entre las Fases I y II y se diluye en la III; (b) la posición de enterramiento decúbito dorsal extendida; (c) los cobertores de esteras vegetales, pieles de camélido, ave y lobo marino; (d) el uso de faldellines vegetales y/o fibra de camélido; (e) inhumaciones bajo la arena sin construcción de tumbas; (f) inhumaciones más bien superficiales; $(\mathrm{g})$ predominio en la orientación sacro-vértex de los cuerpos hacia el NE, aunque ésta es más recurrente en los cuerpos con momificación artificial; (h) la tecnología y la economía continúan siendo básicamente marítimas.

\section{Los Bienes Funerarios del Sitio Morro 1}

Los individuos con momificación natural son los más numerosos y tienen la mayor cantidad y variedad de objetos asociados (Tablas 3 y 4); de los 301 especímenes tabulados, 184 se asocian a este tipo de individuos; 39 a individuos con pátina de arena; 23 a individuos con momificación artificial y 55 se ubicaron en superficie y sectores removidos, sin una clara asociación a cuerpos específicos. La totalidad de los objetos analizados fueron agrupados en los siguientes rubros: (1) objetos relacionados con la vestimenta; (2) implementos para la explotación de los recursos marinos; 
Tabla 2. Indicadores funerarios del sitio Morro 1. Cultural funerary features, site Morro 1.

\begin{tabular}{|c|c|c|c|}
\hline Rasgos funerarios & $\mathrm{MN}$ & MCA & MA \\
\hline Enterramientos secundarios & & & $\mathrm{x}$ \\
\hline $\begin{array}{l}\text { Patrón homogéneo en la orientación } \\
\text { de los cuerpos }\end{array}$ & & & $\mathrm{x}$ \\
\hline Enterramientos colectivos & & & $\mathrm{x}$ \\
\hline Mínimas ofrendas a los cuerpos & & & $\mathrm{x}$ \\
\hline $\begin{array}{l}\text { Emplantillado de huesos (otaria y } \\
\text { cetáceos) sobre el cuerpo }\end{array}$ & & & $\mathrm{x}$ \\
\hline Enterramientos individuales & $\mathrm{x}$ & $\mathrm{x}$ & $\mathrm{x}$ \\
\hline Cuerpos extendidos decúbito dorsal & $\mathrm{x}$ & $\mathrm{x}$ & $\mathrm{x}$ \\
\hline Cuerpos cubiertos con esteras & $\mathrm{x}$ & $\mathrm{x}$ & $\mathrm{x}$ \\
\hline $\begin{array}{l}\text { Cuerpos vestidos con faldellines } \\
\text { de fibra de camélido }\end{array}$ & $\mathrm{x}$ & $\mathrm{x}$ & $\mathrm{x}$ \\
\hline $\begin{array}{l}\text { Cuerpos vestidos con faldellines } \\
\text { de fibra vegetal }\end{array}$ & $\mathrm{x}$ & $\mathrm{x}$ & $\mathrm{x}$ \\
\hline $\begin{array}{l}\text { Uso de cintillos cefálicos (fibra } \\
\text { vegetal o camélido) }\end{array}$ & $\mathrm{x}$ & $\mathrm{x}$ & $\mathrm{x}$ \\
\hline $\begin{array}{l}\text { Uso de gorros o cobertores } \\
\text { cefálicos }\end{array}$ & $\mathrm{x}$ & $\mathrm{x}$ & $\mathrm{x}$ \\
\hline $\begin{array}{l}\text { Inhumación directa bajo la arena, } \\
\text { sin construcción de tumbas }\end{array}$ & $\mathrm{x}$ & $\mathrm{x}$ & $\mathrm{x}$ \\
\hline $\begin{array}{l}\text { Predominio de entierros } \\
\text { individuales }\end{array}$ & $\mathrm{x}$ & $\mathrm{x}$ & \\
\hline Enterramientos primarios & $\mathrm{x}$ & $\mathrm{x}$ & \\
\hline $\begin{array}{l}\text { Cuerdas entrelazadas en los dedos } \\
\text { (fibra vegetal o camélido) }\end{array}$ & $\mathrm{x}$ & $\mathrm{x}$ & \\
\hline $\begin{array}{l}\text { Deformación cefálica intencional, } \\
\text { predominio Circular Oblicua }\end{array}$ & $\mathrm{x}$ & $\mathrm{x}$ & \\
\hline $\begin{array}{l}\text { Tatuaje facial de puntos sobre labio } \\
\text { superior }\end{array}$ & $\mathrm{x}$ & & \\
\hline Tapones nasales & $\mathrm{x}$ & & \\
\hline
\end{tabular}

MN: Momias naturales.

MCA: Momias capa de arena.

MA: Momias artificiales.

(3) implementos para tareas relacionadas con la caza terrestre; (4) implementos relacionados al probable uso de sicotrópicos; (4) contenedores: bolsas y cubiletes de hueso, y (5) material misceláneo.

\section{Vestimenta y ornamentación de los individuos}

La vestimenta registrada en los tres patrones funerarios consistió en prendas para cubrir la región genital de los individuos, y se identificaron dos tipos: (a) faldellines y (b) cobertores púbicos; predominando el uso del primero, con 52 especímenes $(84 \%)$ y sólo 10 cobertores púbicos (16\%), ambos confeccionados en fibra vegetal y/o la fibra de camélido (hilada y torcida). Se usó la planta de totora y del junquillo, disponibles en el tramo inferior de la desembocadura de los valles de Azapa y Lluta. La fibra de camélido plantea ciertos problemas, ya que no es posible aún identificar a nivel de especie el tipo de fibra utilizada (vicuña o guanaco, o eventualmente alguna especie domesticada?).

Faldellines. De los 52 faldellines, 29 se elaboraron en fibra vegetal, 22 en fibra de camélido y uno, en ambas materias primas. La técnica de confección varía por materia prima: (a) el faldellín vegetal se elaboró con una fibra fina, generalmente no torcida, con un largo entre 50-70 cm, para los adultos. Luego se doblaba sobre sí misma y se pasaba un cordón interno, finalmente se introducía un tercer elemento, a modo de una trama que se entrecruzaba después de fijar el haz de fibra colgante (Figura 2a y b) que cubría hasta medio muslo. Hay variaciones en la técnica constructiva, y algunos faldellines muestran los haces con torsión (Figura 2c y d). Este tipo de faldellín fue descrito por Uhle (1919:11) como "delantal", porque solo cubría la parte anterior del cuerpo; (b) el faldellín de fibra de camélido se elaboró con una técnica más compleja; con la progresión de un solo elemento, hilado y torcido, que tiene continuidad desde el inicio hasta terminar la prenda. En la parte que se fija a la cadera, la cuerda hace un looping, y los pabilos colgantes son torcidos y retorcidos, distribuyéndose en todo el contorno de la pelvis (Figura 3a). Tienen una longitud promedio de $30 \mathrm{~cm}$, y cubren hasta medio muslo. Dos faldellines son de elaboración más compleja, con la combinación de colores naturales beige y café, formando diseños estructurales e incorporando flecos terminales en los pabilos (Figura $3 b)$. Estos últimos se asocian exclusivamente a individuos con momificación natural, con dataciones posteriores a los 3.800 a.p.

Generalmente un mismo individuo lleva un faldellín de fibra de camélido y sobre éste, otro de fibra vegetal, llegando a tener hasta tres superpuestos. Los faldellines están asociados a los tres patrones funerarios: 19 individuos con momificación natural, seis con pátina de arena y siete con momificación artificial. Hay más mujeres con faldellín, de los 32 individuos que lo llevan puesto o asociado, $20(60 \%)$ corresponden a mujeres, tres $(9,4 \%)$ a hombres, y en nueve casos (28\%) no fue posible 
Tabla 3. Cuantificación de los bienes culturales del sitio Morro 1 y su relación con el patrón funerario. Frequency of cultural items, site Morro 1 and its relation to funerary patterns.

\begin{tabular}{|c|c|c|c|c|c|}
\hline Bienes culturales & $\mathrm{MN}$ & MCA & MA & $\mathrm{S} / \mathrm{R}$ & Total \\
\hline Penetradores espina mantarraya* & 38 & 0 & 0 & 0 & 38 \\
\hline Cabezales de arpón de madera & 22 & 1 & 0 & 14 & 37 \\
\hline Faldellín fibra vegetal & 14 & 7 & 6 & 3 & 30 \\
\hline Faldellín fibra camélido & 12 & 2 & 1 & 7 & 22 \\
\hline Bolsas redes fibra vegetal & 14 & 0 & 0 & 6 & 20 \\
\hline Cintillos cefálicos fibra camélido y/o vegetal & 10 & 3 & 3 & 0 & 16 \\
\hline Bolsitas de cuero & 6 & 3 & 4 & 0 & 13 \\
\hline Desconchadores o chopes de hueso & 7 & 0 & 0 & 2 & 9 \\
\hline Cubiletes de hueso & 4 & 3 & 0 & 0 & 7 \\
\hline Cobertores púbicos fibra vegetal y/o camélido & 4 & 1 & 1 & 0 & 6 \\
\hline Astiles para arpón de madera & 4 & 0 & 0 & 2 & 6 \\
\hline Anzuelos de espina vegetal & 3 & 1 & 0 & 2 & 6 \\
\hline Cuerdas de fibra camélido & 3 & 3 & 0 & 0 & 6 \\
\hline Estólicas & 0 & 2 & 1 & 3 & 6 \\
\hline Dardos & 5 & 1 & 0 & 0 & 6 \\
\hline Lanzas? & 5 & 1 & 0 & 0 & 6 \\
\hline Palitos de madera para hilar? & 2 & 1 & 0 & 2 & 5 \\
\hline Cobertores cefálicos "gorros" (piel de ave) & 2 & 1 & 1 & 0 & 4 \\
\hline Barbas de hueso para arpón & 2 & 2 & 0 & 0 & 4 \\
\hline Arcos? & 1 & 0 & 0 & 3 & 4 \\
\hline Cuentas de concha & 4 & 0 & 0 & 0 & 4 \\
\hline Lajas líticas & 1 & 1 & 2 & 0 & 4 \\
\hline Barba de espina vegetal para arpón & 1 & 0 & 0 & 2 & 3 \\
\hline Arponcillos de hueso para pesca & 1 & 0 & 0 & 2 & 3 \\
\hline Pesas líticas & 0 & 1 & 1 & 1 & 3 \\
\hline Sedales de cuerda vegetal & 1 & 1 & 0 & 1 & 3 \\
\hline Puntas líticas de proyectil & 1 & 0 & 0 & 2 & 3 \\
\hline Espátulas de hueso & 1 & 1 & 0 & 1 & 3 \\
\hline Bolsas tubulares (fibra camélido) & 1 & 2 & 0 & 0 & 3 \\
\hline Cestería coiled & 3 & 0 & 0 & 0 & 3 \\
\hline Yesqueros & 0 & 0 & 2 & 0 & 2 \\
\hline Cuentas de semilla (Mucuna elliptica?) & 2 & 0 & 0 & 0 & 2 \\
\hline Collar de conchas & 2 & 0 & 0 & 0 & 2 \\
\hline Cuentas líticas & 1 & 0 & 0 & 0 & 1 \\
\hline Cuenta de hueso & 1 & 0 & 0 & 0 & 1 \\
\hline Aguja vegetal & 0 & 0 & 1 & 0 & 1 \\
\hline Alfiler vegetal & 1 & 0 & 0 & 0 & 1 \\
\hline Apretador de trama (hueso) & 1 & 0 & 0 & 0 & 1 \\
\hline Punzón de hueso & 1 & 0 & 0 & 0 & 1 \\
\hline Lima de arenisca & 1 & 0 & 0 & 0 & 1 \\
\hline Cuchillo enmangado & 1 & 0 & 0 & 0 & 1 \\
\hline Hoja lítica bifacial tipo cuchillo & 0 & 1 & 0 & 0 & 1 \\
\hline Tubo de hueso & 1 & 0 & 0 & 0 & 1 \\
\hline Tableta madera & 0 & 0 & 0 & 1 & 1 \\
\hline Tortero hueso & 0 & 0 & 0 & 1 & 1 \\
\hline Total de ítemes por patrón funerario & 184 & 39 & 23 & 55 & 301 \\
\hline
\end{tabular}

MN: Momias naturales.

MCA: Momias capa de arena.

MA: Momias artificiales.

S/R: Superficie y sectores removidos.

* Asociadas a sólo un individuo (M1T11) 
Tabla 4. Bienes culturales sitio Morro 1 y su relación con el patrón de momificación.

Cultural items in relation to mummification patterns.

\begin{tabular}{|c|c|c|c|}
\hline Bienes culturales & $\mathrm{MN}$ & MCA & MA \\
\hline 1. Yesquero & & & $\mathrm{x}$ \\
\hline 2. Aguja de espina vegetal & & & $\mathrm{x}$ \\
\hline 3. Pesas líticas & & $\mathrm{x}$ & $\mathrm{x}$ \\
\hline 4. Estólicas & & $\mathrm{x}$ & $\mathrm{x}$ \\
\hline 5. Brochas vegetales & $\mathrm{x}$ & $\mathrm{x}$ & $\mathrm{x}$ \\
\hline 6. Bolsitas de cuero camélido & $\mathrm{x}$ & $\mathrm{x}$ & $\mathrm{x}$ \\
\hline 7. Esteras vegetales técnica twining & $\mathrm{x}$ & $\mathrm{x}$ & $\mathrm{x}$ \\
\hline 8. Faldellines fibra vegetal & $\mathrm{x}$ & $\mathrm{x}$ & $\mathrm{x}$ \\
\hline 9. Faldellines fibra camélido & $\mathrm{x}$ & $\mathrm{x}$ & $\mathrm{x}$ \\
\hline 10. Cobertor púbico fibra vegetal & $\mathrm{x}$ & $\mathrm{x}$ & $\mathrm{x}$ \\
\hline $\begin{array}{l}\text { 11. Cobertor púbico fibra } \\
\text { camélido }\end{array}$ & $x$ & X & $x$ \\
\hline 12. Cintillos cefálicos & $\mathrm{x}$ & $\mathrm{x}$ & $\mathrm{x}$ \\
\hline 13. Cobertor cefálico (piel de ave) & $\mathrm{x}$ & $\mathrm{x}$ & $\mathrm{x}$ \\
\hline 14. Cordelería fibra camélido & $\mathrm{x}$ & $\mathrm{x}$ & $\mathrm{x}$ \\
\hline 15. Cordelería fibra vegetal & $\mathrm{x}$ & $\mathrm{x}$ & $\mathrm{x}$ \\
\hline 16. Cordelería pelo humano & $\mathrm{x}$ & $\mathrm{x}$ & $\mathrm{x}$ \\
\hline 17. Piedras lajas & $\mathrm{x}$ & $\mathrm{x}$ & $\mathrm{x}$ \\
\hline 18. Anzuelos espina vegetal & $\mathrm{x}$ & $\mathrm{x}$ & \\
\hline 19. Sedales para pesca (fibra vegetal) & $\mathrm{x}$ & $\mathrm{x}$ & \\
\hline 20. Cabezales madera para arpón & $\mathrm{x}$ & $\mathrm{x}$ & \\
\hline 21. Barbas de hueso para arpón & $\mathrm{x}$ & $\mathrm{x}$ & \\
\hline 22. Dardos? & $\mathrm{x}$ & $\mathrm{x}$ & \\
\hline 23. Lanzas? & $\mathrm{x}$ & $\mathrm{x}$ & \\
\hline 24. Palitos para hilar fibra camélido ? & $\mathrm{x}$ & $\mathrm{x}$ & \\
\hline $\begin{array}{l}\text { 25. Bolsitas tubulares de fibra } \\
\text { de camélido }\end{array}$ & & & \\
\hline de camélido & $\mathrm{x}$ & $\mathrm{x}$ & \\
\hline 26. Cubiletes o contenedores de hueso & $\mathrm{x}$ & $\mathrm{x}$ & \\
\hline 27. Espátulas de hueso & $\mathrm{x}$ & $\mathrm{x}$ & \\
\hline 28. Cuentas discoidales de concha & $\mathrm{x}$ & $\mathrm{x}$ & \\
\hline 29. Cuentas de Mucuna elliptica? & $\mathrm{x}$ & $\mathrm{x}$ & \\
\hline 30. Arponcillos de hueso & $\mathrm{x}$ & & \\
\hline $\begin{array}{l}\text { 31. Barbas de espina vegetal para } \\
\text { arpón }\end{array}$ & $\mathrm{x}$ & & \\
\hline 32. Astiles y/o portarpones & $\mathrm{x}$ & & \\
\hline 33. Desconchadores o chopes & $\mathrm{x}$ & & \\
\hline $\begin{array}{l}\text { 34. Penetradores espinas } \\
\text { de mantarraya }\end{array}$ & $\mathrm{x}$ & & \\
\hline 35. Punzón de hueso & $\mathrm{x}$ & & \\
\hline 36. Cuchillo lítico enmangado & $\mathrm{x}$ & & \\
\hline 37. Arcos? & $\mathrm{x}$ & & \\
\hline 38. Bolsas redes (tipo chinguillo) & $\mathrm{x}$ & & \\
\hline 39. Lima arenisca & $\mathrm{x}$ & & \\
\hline 40. Cuenta discoidal malaquita & $\mathrm{x}$ & & \\
\hline 41. Cuenta tubular de hueso & $\mathrm{x}$ & & \\
\hline 42. Apretador de trama? & $\mathrm{x}$ & & \\
\hline $\begin{array}{l}\text { 43. Tejido de fibra de camélido } \\
\text { (twining) }\end{array}$ & $\mathrm{x}$ & & \\
\hline 44. Cestería en espiral & $\mathrm{x}$ & & \\
\hline 45. Alfiler de espina vegetal & $\mathrm{x}$ & & \\
\hline 46. Tubo de hueso (aspirar ?) & $\mathrm{x}$ & & \\
\hline 47. Faja telar de cintura & & $\mathrm{x}$ & \\
\hline 48. Fragmento tableta de madera* & & & \\
\hline 49. Tortero de hueso* & & & \\
\hline $\begin{array}{l}\text { 50. Puntas proyectil pequeña } \\
\text { (lanceolada bifacial)* }\end{array}$ & & & \\
\hline
\end{tabular}

MN: Momias naturales.

MCA: Momias capa de arena.

MA: Momias artificiales.

* Material de superficie y sectores removidos. identificar el sexo de los individuos. Abarcan todo el rango de edades desde neonatos hasta adultos, incluso algunos fetos y estatuillas de arcilla portan faldellines.

Cobertores púbicos. Se confeccionaron en fibra de camélido y/o vegetal, y se registraron ocho casos, de los cuales cuatro se elaboraron tejiendo un paño rectangular entre 5 a $6 \mathrm{~cm}$ de ancho por 12 a $13 \mathrm{~cm}$ de largo, que cubría la región por debajo del ombligo hasta los genitales. Tejidos de un solo elemento, con la técnica del anillado con enlace simple (Emery 1966; Ulloa 1974), luego el tejido se une a un cordón de fibra de camélido, con el cual era fijado a la pelvis. Semejan una bolsa tubular, a no ser que algunas bolsas de este tipo cumplieran la función de cobertores púbicos en el hombre, como en los cazadores Selknam de Tierra del Fuego (Chapman 1988).

Un cobertor púbico más complejo, elaborado en fibra de camélido, con técnica de twining (tejido de dos elementos, de trama torcida), consiste en un paño que después de cubrir los genitales, los pabilos sueltos (las urdimbres) fueron embarrilados con una cuerda, formando un cordón circular que asciende por la zona interglútea, y se fijaba a la pelvis con un cordón de fibra de camélido (Figura 4). Aunque se ubicó cercano a una mujer adulta, no estaba in situ, además el sector fue removido y el cuerpo erosionado, por lo que puede no ser su posición original. El registro de un madejón de cuerdas de fibra de camélido, a nivel pélvico, en una mujer adulta con momificación artificial, escapa al patrón. Aunque la parte central está erosionada, por lo que no se puede conocer la forma completa y si efectivamente corresponde a un cobertor púbico. Finalmente, dos casos corresponden solo a cuerdas de fibra de camélido amarradas a la pelvis, que se interpretan como restos de cobertores púbicos.

Los cobertores púbicos, al igual que los faldellines, se encontraron asociados a los tres patrones funerarios, y hay cierta tendencia a ser más comunes en los hombres (cuatro masculinos y dos femeninos).

Cobertores púbicos de cuero. Se denominan así a unos cueritos (probablemente camélido) puestos en el pubis, en individuos con momificación artificial. Tienen un ancho promedio de $5 \mathrm{~cm}$ y cubren por debajo del ombligo hasta el pubis; fueron pintados de rojo y están sujetos a la cadera por una cuerda vegetal. Se asocian a dos mujeres jóvenes, las cua- 

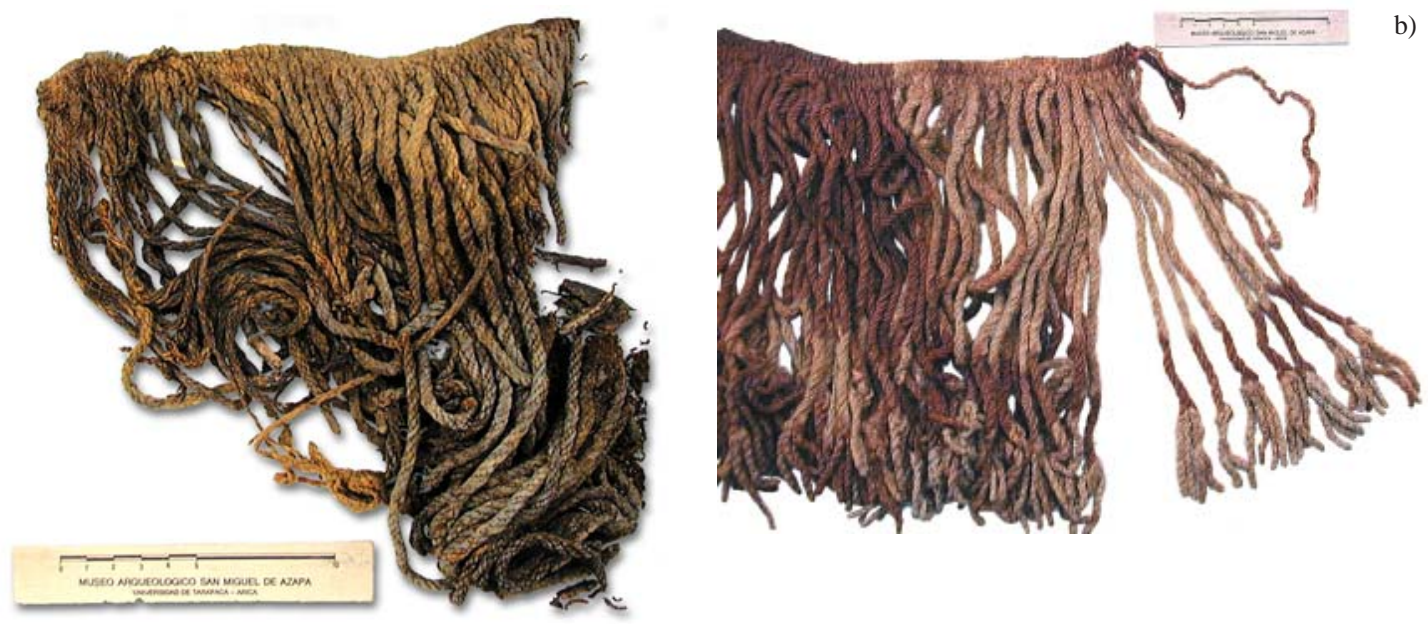

Figura 3. Faldellines de fibra de camélido: (a) con pabilos hilados y torcidos, distribuidos en todo el contorno de la pelvis; (b) de elaboración más compleja, con la combinación de colores naturales beige y café formando diseños estructurales y incorporando flecos terminales en los pabilos, (escala: $10 \mathrm{~cm}$ ).

Camelid fiber fringe skirt: (a) spun and plied cords, wrapped around the pelvis; (b) more complex manufacture. This includes a pattern of natural beige and brown colors and cords with fringed ends, (scale: $10 \mathrm{~cm})$.

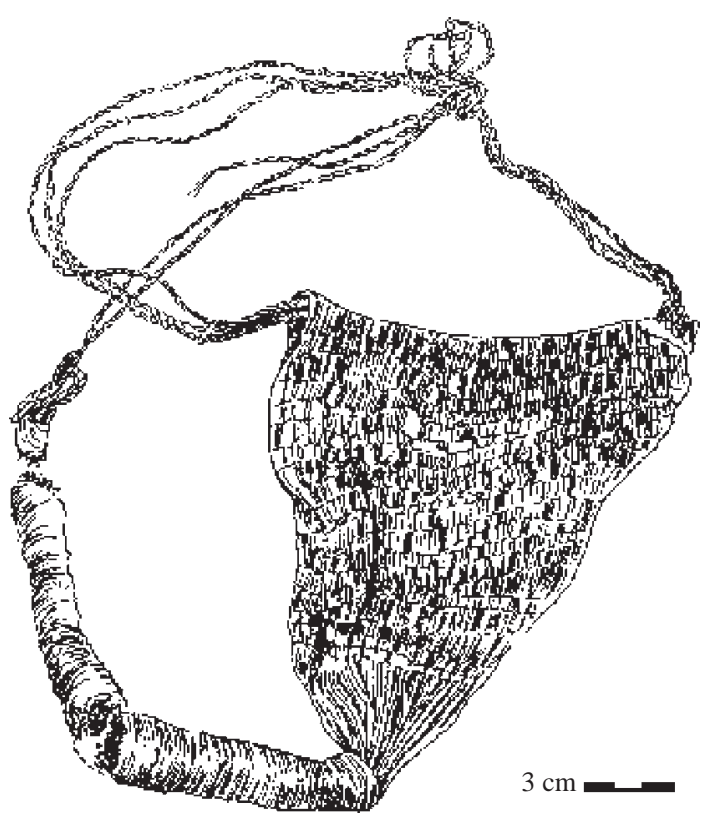

Figura 4. Cobertor púbico elaborado en fibra de camélido, con técnica de twining.

Breechcloth made of camelid cords and a twined technique.

les tienen puesto un faldellín de fibra vegetal sobre éstos.

Faja. Se registró solo un ejemplar que se ubicó cerca de una inhumación disturbada que conservó solo el cráneo (adulto femenino, con pátina de arena). Esta es la única pieza textil (Figura 5) elaborada probablemente en telar de cintura registrada en el sitio, con un fechado posterior a los 3.800 a.p. Podría haber estado relacionada con la práctica de la deformación del cráneo, tal como se registran en Tiliviche 2 (Standen y Núñez 1984).

Cintillos cefálicos. Se registraron 16 casos de cintillos cefálicos (además de abundantes cuerdas aisladas de fibra de camélido y cabello humano que, entre otras funciones, debieron ser parte de cintillos). El $75 \%$ fueron elaborados en fibra de camélido y el 25\% de cabello humano. En general se trata de cuerdas delgadas (1-3 mm diámetro), sólo en dos casos se observa un cordón grueso $(7 \mathrm{~cm}$ diámetro) formando un cintillo más abultado. Con relación a la torsión, hay cierta tendencia a (z)S y retorcidos en $\mathrm{Z}$, cuando forman un cordón.

Estos cintillos fueron usados durante todo el ciclo de vida y en ambos sexos, aunque hay cierta tendencia a ser más populares en los hombres adultos. Su uso constituyó una tradición, ya que está asociado a los tres patrones funerarios. Hay tres lactantes con momificación artificial que lo presentan, 10 individuos con momificación natural y tres con pátina de arena. De los 16 casos, el 44\% está constituido por neonatos y lactantes. Esta relación tiene coherencia con el registro de cráneos 


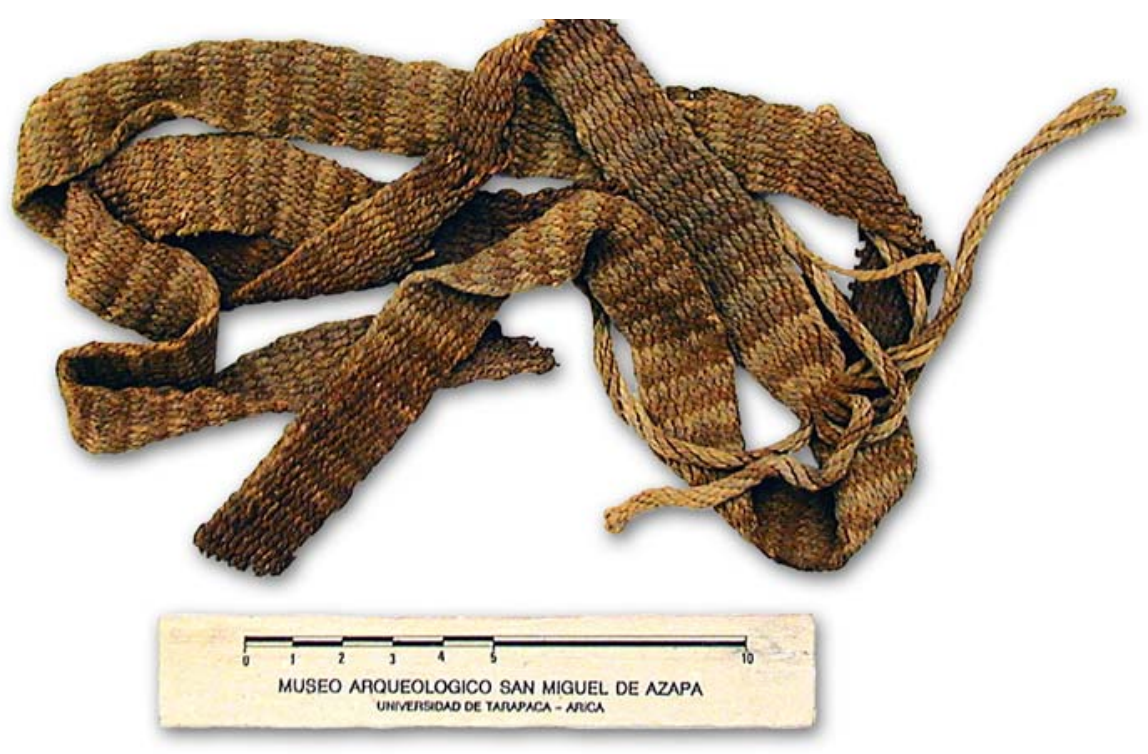

Figura 5. Faja elaborada en fibra de camélido, con técnica en telar de cintura. Tiene $5 \mathrm{~cm}$ de ancho por $80 \mathrm{~cm}$ de largo. Las urdimbres están alternando colores café y beige (ambos naturales), lo que da una decoración estructural, (escala: $10 \mathrm{~cm}$ ).

Belt made with camelid fiber $(5 \mathrm{~cm}$ in diameter by $80 \mathrm{~cm}$ in long). Back-strap loom woven. The warp has a pattern of alternating brown and beige natural colors, (scale: $10 \mathrm{~cm}$ ).

deformados con el patrón circular, que se produce, entre otros, por el uso de cintillos (Oscar Espouys, comunicación personal; Munizaga 1980; Soto 1974, 1987). Además se siguieron usando en la etapa de la niñez y adulta, aunque ya el cráneo estuviera deformado. Los cintillos dispuestos sobre pieles de camélido y ave, y el registro de un individuo con momificación artificial con el cintillo sobre la mascarilla facial, demuestra que también los colocaron durante la elaboración de las momias.

Cobertores cefálicos o "gorros". Corresponden a unos cueritos que cubrían la cabeza; fueron elaborados en piel de pelícano, pintada de rojo. Por la mala preservación del material, no fue posible determinar la forma específica que tenían, aunque se observan costuras en su elaboración. Se registran sólo cuatro casos, asociados a los tres patrones funerarios, sin distinción de edades ni sexos. Especímenes similares se reconocen en Camarones 14 (Schiappacasse y Niemeyer 1984), y Uhle (1919) señala que algunas momias de Arica presentaban la cabeza cubierta con un tejido de red y un capuchón de estera vegetal.
Mantas de pieles. Cubrían el cuerpo con mantas elaboradas de piel de camélido o en menor frecuencia en pieles de pelícano y cuero de lobo marino. Las pieles se cocieron para formar paños más grandes. Generalmente se llevaban con el vellón en contacto al cuerpo, y las de pelícano, con las plumas hacia fuera. Se asocian a los tres patrones funerarios, aunque con mayor frecuencia a los individuos con momificación natural.

Collares y cuentas. Hay tanto collares enhebrados, como cuentas aisladas. La materia prima dominante fue la valva de Choromytilus, también hay presencia de semillas (probablemente Mucuna elliptica), cuentas óseas y líticas. Las elaboradas en concha son de forma discoidal planiforme con diámetros que fluctúan entre $1-3,5 \mathrm{~cm}$. Se registró un collar de cuentas de concha puesto en el cuello de un niño. Las cuentas óseas, minoritarias en la muestra (dos casos) son de forma tubular ( $1 \mathrm{~cm}$ de alto por $0,8 \mathrm{~cm}$ de diámetro) elaboradas en diáfisis de ave. Las semillas son pequeñas, con un diámetro promedio de $0,3 \mathrm{~cm}$, de forma esferoidal, contextura dura y con una cutícula negra brillante. Se ubicaron en dos fragmentos de collar y fueron elaborados con la combinación de 
cuentas de concha. Se registró solo una cuenta de malaquita $(2,1 \mathrm{~cm}$ diámetro por $0,7 \mathrm{~cm}$ de grosor) contenida en la mano de un infante.

Ocho individuos tienen cuentas y collares, tanto los con momificación natural y los con pátina de arena; de ambos sexos y todas las edades. Las semillas, probablemente Mucuna elliptica, se asocian sólo a dos individuos, datados después de los 3.800 a.p.

\section{Implementos para la explotación marítima}

Estos implementos (Figura 6a-h) se relacionan con diversas actividades llevadas a cabo en el medio ambiente costeño, donde fue dominante la caza de mamíferos marinos y peces con técnicas de arponeo, la pesca de peces con anzuelos y la recolección de moluscos.

Cabezales de arpón de madera. Tienen entre 18 y $32 \mathrm{~cm}$ de longitud por 1 a $1,5 \mathrm{~cm}$ de diámetro, de sección circular. Fueron elaborados en maderas locales (probablemente Prosopis sp.) y todos muestran un proceso de fabricación relativamente homogéneo. Ambos extremos fueron aguzados; el proximal tiene la típica abertura para introducir la hoja, que era fijada con un embarrilado de fibra de camélido y/o vegetal, y sobre éste una pátina de brea; algunos muestran un aplanamiento, para adosar una barba, que era de hueso o espina vegetal. El extremo distal se adelgaza para introducirlo al astil (Figura 6c). La diferencia de tamaño de los arpones podría vincularse con distintas clases de presas y funciones propias de la caza. Dos arpones fueron pintados de rojo y uno amarillo.

Se registraron 37 especímenes, de los cuales 23 están asociados a 15 individuos ( 14 con momificación natural y uno con pátina de arena). Lo portan tanto hombres como mujeres, en su mayoría adultos. Los 14 arpones restantes se localizaron en áreas disturbadas, sin asociación a cuerpos específicos. Llama la atención que a pesar del alto número registrado, ninguno tuvo su punta, la cual podría haber sido conservada. Estos artefactos fueron también usados como armas con resultado de muerte, en situaciones belicosas y de conflictos (Standen y Arriaza 2000).

Arponcillos de hueso para la pesca. Se registraron solo tres ejemplares, uno elaborado en hueso de camélido, y los dos restantes en hueso de ave (Fi- gura $6 \mathrm{~b}$ y f), que contrasta con el número más alto de los elaborados en madera. Presentan indistintamente barbas de hueso o espina vegetal. Un arponcillo está asociado a un adulto masculino con momificación natural, y los dos restantes fueron ubicados en sectores disturbados.

Astiles para cabezal de arpón. Corresponden al portacabezal que completa el funcionamiento del arpón. Se elaboraron en madera, con un diámetro que oscila entre 2,5-3,3 cm; el largo total se desconoce ya que las evidencias corresponden solo a fragmentos; el de mayor tamaño conserva un largo de 1,20 m. Para resolver el problema de la longitud requerida, acoplaron dos maderos, haciendo un rebaje oblicuo en cada uno de los extremos, luego pusieron una resina y lo embarrilaron con una cuerda de fibra de camélido (Figura 6a). Se registraron seis fragmentos de astiles: cuatro se asocian a individuos con momificación natural, masculinos adultos. Los dos restantes fueron localizados en el relleno del sector T-27, sin asociación a cuerpos específicos.

Barbas para arpón. Se registraron siete ejemplares (cuatro óseas y tres de espina vegetal), de las cuales cuatro estaban en el cabezal del arpón (Figura 6d), dos estaban en el interior de una bolsa que contenía tubos de hueso y cordelería, y la otra estaba aislada. Se observa una leve tendencia a ofrendarlas más a los hombres: tres adultos masculinos (las barbas óseas) y un adulto femenino (la barba de espina vegetal), y están asociadas a individuos con momificación natural y con pátina de arena. Las dos restantes fueron localizados en el relleno del sector T-27, sin asociación a cuerpos específicos.

Anzuelos de espina vegetal. Se registraron seis ejemplares, con notables diferencias de tamaños, miden entre 1,2 a $6,3 \mathrm{~cm}$ de alto, y 0,8 a $2,4 \mathrm{~cm}$ de ancho. Tienen el típico vástago rectilíneo y luego la curvatura (Figura 6g). La diferencia entre los tamaños (Figura 7) podría correlacionarse con el tipo de presas que capturaban. Se observa cierta tendencia a depositarlos en mujeres con momificación natural y con pátina de arena (tres mujeres adultas y un infante), más dos ejemplares de sectores removidos. En su mayoría se ubican prendidos en las bolsas chinguillo que contienen los utensilios de la pesca. 


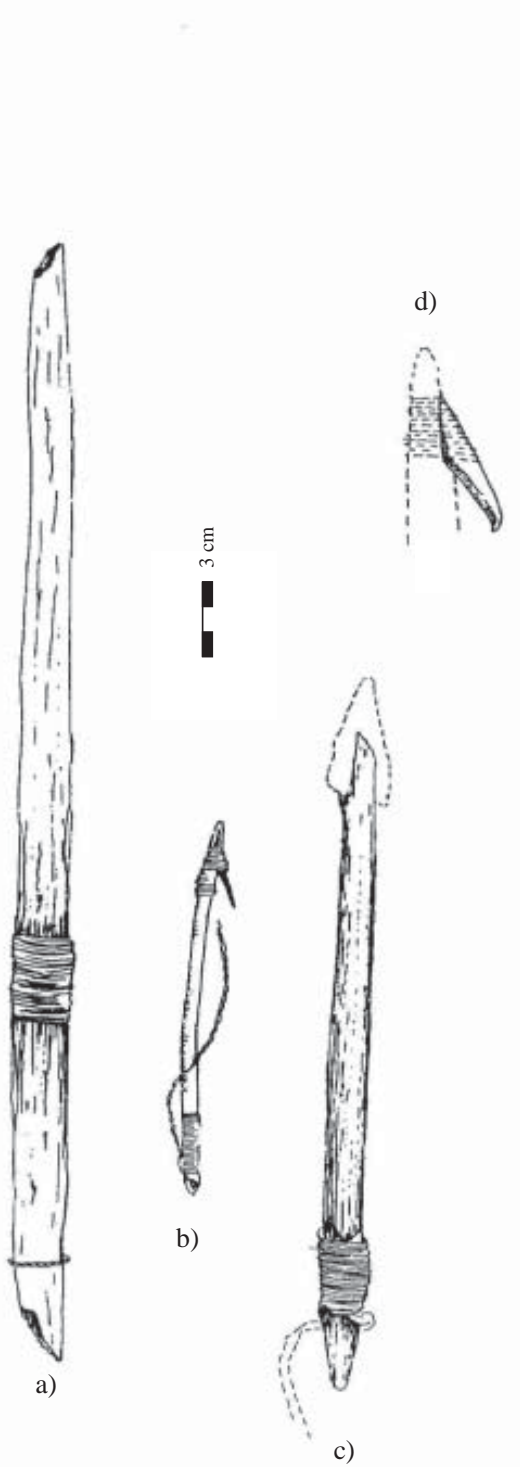

c)

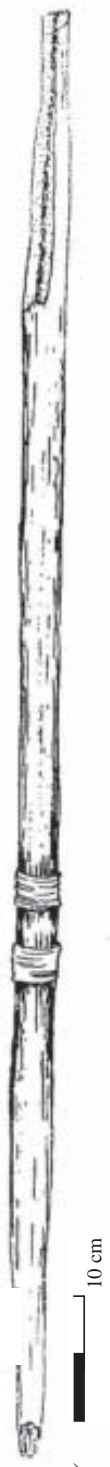

e)
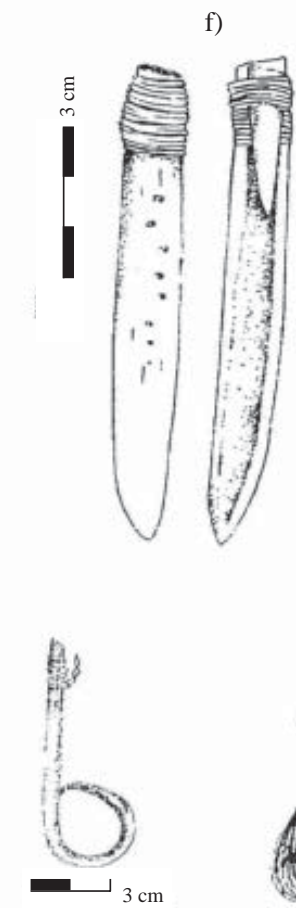

g)

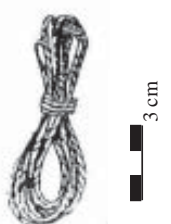

h)

Figura 6. (a) astil de arpón elaborado en madera; (b) arponcillo de hueso con barba de espina vegetal; (c) cabezal de arpón de madera; (d) barba de hueso para cabezal de arpón; (e) dardo de madera; (f) cabezal de arpón de hueso (anverso y reverso); (g) anzuelo de espina vegetal; (h) sedal de fibra vegetal.

(a) wooden harpoon shaft; (b) small bone harpoon with thorn barb; (c) wooden harpoon head; (d) barb bone tip; (e) wooden dart; (f) bone harpoon head; $(g)$ thorn hook; $(h)$ fishing line of vegetal fiber.

Sedales de fibra vegetal para la pesca. Se registraron dos ovillos (de dos cabos con torsión s) (Figura 6h), uno está amarrado a la pesa lítica, asociado a una mujer adulta con pátina de arena, y el otro en una zona disturbada.

Pesas líticas. Se registraron tres ejemplares bien definidos; son de forma ovoidal y/o esferoidal (en- tre 2 a $3 \mathrm{~cm}$ de diámetro) con presencia de sedales in situ. Una pesa muestra la típica hendidura que servía para amarrar el sedal y estaba asociada a una mujer con pátina de arena; otro ejemplar tiene un embarrilado circular de tendón y bajo éste un embarrilado de cuerda vegetal, asociado a una mujer con momificación artificial. El tercer ejemplar se ubicó en un sector removido. Además se 
registró una cantidad de pequeñas piedras esferoidales, oblongas u ovoidales, sin huellas de amarres o evidencias más claras para atribuirles la función de pesas. Pudieron servir también como hondas para la captura de aves, o como armas, en conflictos entre los diversos grupos que habitaban en la desembocadura de los valles (Standen y Arriaza 2000).

Bolsas de red (chinguillo). Fueron elaboradas en fibra vegetal (Figura 8) y en mínima proporción en fibra tendinosa, con la técnica de anillado con torsión doble (tipo red), a partir de una varilla rígida de forma ovoidal que tenía por función mantener la abertura de la bolsa. Algunas conservaron una cuerda de fibra de camélido para ser colgadas al cuerpo y fueron pintadas de ocre. Una bolsa completa tiene $25 \mathrm{~cm}$ de alto por $32 \mathrm{~cm}$ de ancho; otras están representadas sólo por fragmentos de tejido o la varilla de la boca. Tenían como funciones portar y almacenar los artefactos de la pesca, como bolsas redes para la pesca de peces pequeños o empozados, amarradas a la cintura para la recolección de mariscos buceados o sobre rocas y playas de arena. Además se registró una bolsa red que contenía en su interior huesos de un feto humano.

Se registraron 20 especímenes, de los cuales 14 se asocian a 13 individuos con momificación natural, de ambos sexos y todas las edades (las seis restantes se ubican en sectores removidos).

Cordelería de fibra de camélido. Fue usada en una diversidad de funciones (para amarrar los cabezales de arpón a los astiles, sedales, embarrilados, vestimenta, etc.). Se registran abundantes hilados y torcidos de diversos grosores y torsiones (s y z). Algunas conservan varios metros de longitud y están teñidas con el color púrpura de Concholepas, por lo que se asume su uso en actividades de pesquería. La cordelería está asociada a individuos con momificación natural y con pátina de arena, de ambos sexos.

Desconchadores (Chopes). Artefacto vinculado a la extracción y desconche de mariscos; fueron elaborados en costillas de lobo marino (Figura 9). El extremo proximal se embarrilaba con fibra vegetal o piel de ave marina, y el extremo distal se aguzaba para optimizar su función de palanca y a su vez como penetrador entre la masa cárnea y la concha. Algunos están teñidos casualmente con el color púrpura de la tinta Concholepas, y otros están pintados de rojo.
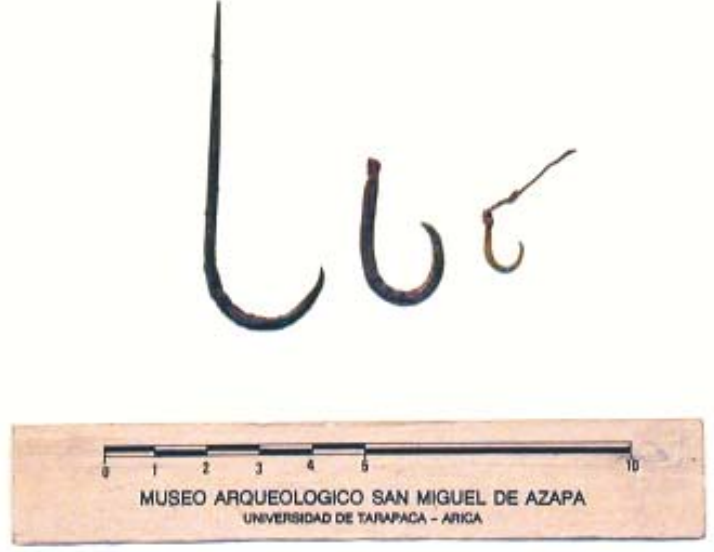

Figura $\%$ Anzuelos de espına vegetal de diversos tamaños (escala: $10 \mathrm{~cm}$ ).

Fish-hooks of thorns of various sizes (scale: $10 \mathrm{~cm}$ ).



Figura 8 . Bolsa de red (chinguillo) elaborada en tibra vegetal. Net (chinguillo) made of vegetal fiber.

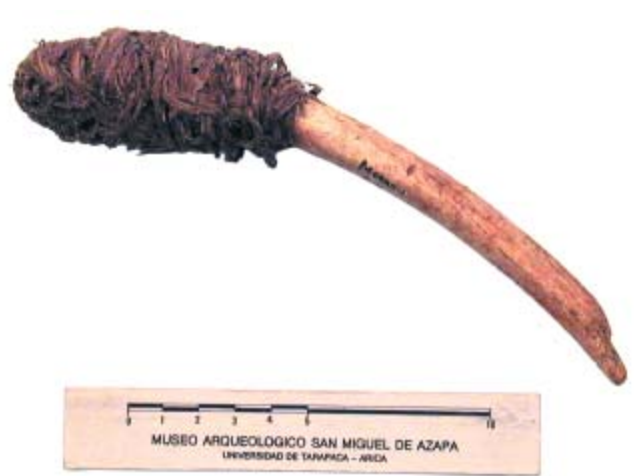

Figura 9. Chope, artefacto de hueso de costillas de lobo marino, vinculado a la extracción y desconche de mariscos. Chope, artifact made of a sea-lion rib used to harvest and pryopen shellfish. 
Se registraron siete especímenes, asociados exclusivamente a individuos con momificación natural, y se distribuyen en dos hombres y una mujer adulta, un niño de sexo indeterminado y un neonato masculino, más dos artefactos sin asociación a cuerpos específicos.

\section{Implementos de caza terrestre}

El registro de estólicas, lanzas, dardos y probables arcos (Figuras 10 y 11) demuestra que la caza terrestre fue otra de las estrategias de apropiación de recursos de esta población.

Estólicas. Se registraron cinco especímenes, que corresponden a dos tipos: (a) de sección circular (tres estólicas), una tiene el gancho tallado en la misma madera, equivalente al tipo D de Rivera y Zlatar (1982), otra con gancho de hueso decorado con diseños lineales; y la tercera no conserva su extremo posterior y el anterior tiene un embarrilado de fibra de camélido y un ojal de sujeción de fibra vegetal (Figuras 10a, b; 11a, b); y (b) con la acanaladura central (Figura 10c) (dos fragmentos de estólica, ambas pintadas de rojo). Se ubicó además una preforma de estólica, lo que podría indicar que fueron elaboradas por el mismo grupo que las usaba.

De los cinco especímenes, sólo tres se asocian a individuos: la estólica con gancho de hueso decorado (Figura 11a, b) se halló paralela a la extremidad superior izquierda de un adulto masculino con momificación artificial estilo negro (M1T1C2) datado (el cuerpo) en 5160 a.p. Las otras dos estólicas se ubicaron junto a individuos con pátina de arena (adultos femeninos), una cercana a la cabeza pero de asociación incierta por tratarse de un sector removido, y la otra paralela al tronco hacia el lado derecho. Las dos estólicas restantes se encontraron en áreas removidas sin asociación a cuerpos específicos.

Arcos. Se registraron cuatro especímenes de probables arcos; sólo uno está completo, mide 74,5 $\mathrm{cm}$ de largo por $2,4 \mathrm{~cm}$ de diámetro, con ambos extremos aguzados (Figura 11c). Los tres restantes presentan el extremo aguzado, sin huellas de amarre. De los cuatro ejemplares, uno se encontró junto a un adulto femenino con momificación natural (pero de asociación incierta por tratarse de un sector removido). Los tres restantes se encontra- ron en áreas disturbadas. Se ubicó además un gran número de maderos de diversos tamaños usados en la preparación de los cuerpos con momificación artificial (ver discusión más adelante).

Dardos. Se registraron seis objetos de madera con un extremo socavado que servía para disponer un penetrador y con huellas de embarrilado de fibra de camélido. Se trata de fragmentos que conservan entre 8,7 a $41,7 \mathrm{~cm}$, de largo con un diámetro entre 0,9 a $2 \mathrm{~cm}$ (Figura 10d). Están asociados a cinco individuos adultos, de ambos sexos, cuatro con momificación natural y uno con pátina de arena. Se ignora qué clase de penetradores usaron, pero a juzgar por la leve perforación, debieron ser finos, como de hueso o espina.

Lanzas. Se trata de seis objetos de madera, donde un extremo fue aguzado, producto de un rebaje concoidal. Un ejemplar completo midió $112 \mathrm{~cm}$ de largo por 2,1 cm de diámetro, los otros son sólo fragmentos. El rebaje debió servir para disponer una hoja lítica, y lograr una penetración a modo de lanza. De los seis ejemplares, cinco se asocian a individuos con momificación natural, y uno, a un individuo con pátina de arena, todos adultos, de ambos sexos. Todos se disponen paralelo al cuerpo hacia el lado derecho; a excepción de un caso que se ubicó sobre las extremidades inferiores (pero de asociación incierta por tratarse de un cuerpo disturbado).

\section{Hojas líticas y penetradores de espina}

Puntas de proyectil. En toda el área excavada se encontraron sólo tres puntas de proyectil; dos ubicadas en el relleno del sector T-23, sin asociación a cuerpos específicos. Son pequeñas y espesas (3 $\mathrm{cm}$ de alto por $1 \mathrm{~cm}$ de espesor) en sílice, de talla bifacial (Figura 12a). Un ejemplar fue embarrilado con fibra vegetal. Otro ejemplar $(1,6 \mathrm{~cm}$ de diámetro por $0,5 \mathrm{~cm}$ de espesor) se ubicó impactada en el hueso escapular de un lobo marino, penetrando por la parte dorsal del animal (Figura 12b). Fue ofrendada, junto a abundantes huesos de cetáceo, a una mujer adulta con momificación artificial incipiente (M1T10B). Otro caso similar se conoce de Camarones 14, donde se encontró una vértebra de lobo marino impactada con una punta de proyectil (Schiappacasse y Niemeyer 1984: Figura 29). 


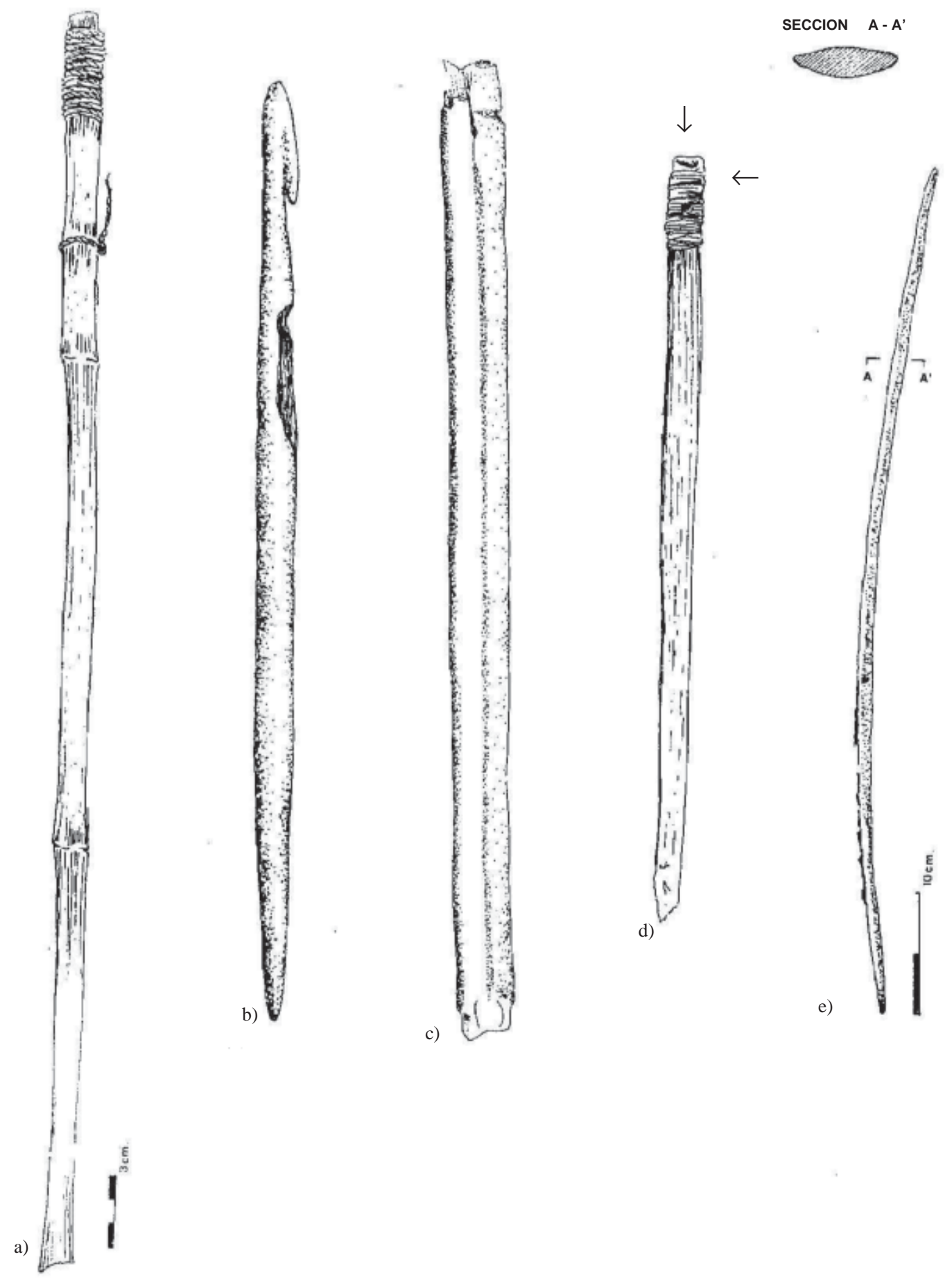

Figura 10. (a) estólica de sección circular, con ojal y embarrilado de fibra vegetal, el gancho no está; (b) estólica de sección circular con gancho tallado en la misma madera; (c) fragmento de estólica con acanaladura central, ausencia de gancho y anillo de sujeción; (d) dardo con orificio y embarrilado para disponer penetrador (indicado por las flechas); (e) madero que estuvo introducido al interior de la extremidad inferior de un cuerpo con momificación artificial (M1/T25/C2).

(a) throwing stick with circular section, a security loop, and vegetal cord wrapping, the thumb hook is missing; (b) throwing stick of circular shaft, with a hook carved in the wood; (c) fragment of a throwing stick with a central depression, but the hook and thumb security loop are missing; (d) dart with orifice and wrapping to adjust its projectil head (indicated by arrows); (e) wooden stick imbed in the lower limb of an artificially mummified body (M1/T25/C2). 



b)

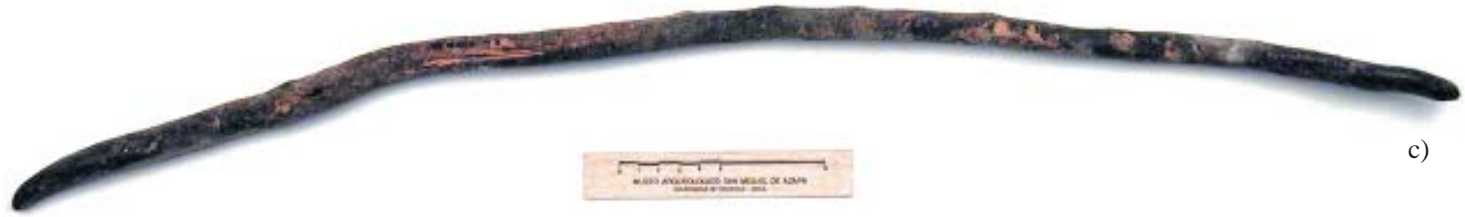

Figura 11. (a) estólica de sección circular con gancho adicional de hueso decorado con incisiones lineales, asociada a un cuerpo con momificación artificial (M1/T1/C2); (b) detalle del gancho decorado; (c) probable arco de madera, (escala $10 \mathrm{~cm}$ ).

(a) throwing stick of circular section with a bone hook with incised lines, associated with an artificially mummified body (M1/T1/C2);

(b) detail of the decorated hook; (c) probable wooden bow, (scale: $10 \mathrm{~cm})$.

a)

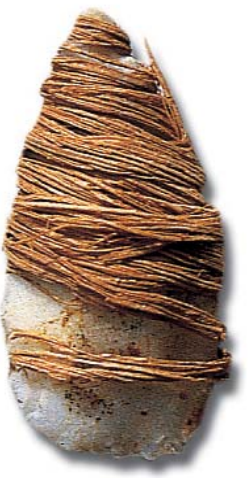



Figura 12. (a) puntas de proyectil, pequeñas y espesas $(3 \mathrm{~cm}$ de alto por $1 \mathrm{~cm}$ de espesor) elaboradas en sílice, talla bifacial. Un ejemplar fue embarrilado con fibra vegetal; (b) punta de proyectil $(1,6 \mathrm{~cm}$ de diámetro por $0,5 \mathrm{~cm}$ de espesor) in situ, en hueso escapular de lobo marino.

(a) small and thick bifacial projectile points (3 $\mathrm{cm}$ in length by $1 \mathrm{~cm}$ in thickness). One projectile point was wrapped with vegetal fiber; (b) Projectile point (1.6 cm in diameter by $0.5 \mathrm{~cm}$ in thickness) embedded in a sea-lion scapula.

Cuchillo enmangado. Hoja triangular, en sílice, de talla bifacial, insertada en un mango de madera (9 $\mathrm{cm}$ de largo). Estuvo asociado a un adulto masculino, con momificación natural.

Cuchillo lítico. Hoja del patrón lanceolado $(8 \mathrm{~cm}$ de largo), en sílice, de talla bifacial; la tiene empu- ñada en la mano una mujer adulta con pátina de barro. Un registro similar fue descrito por Uhle (1919:29) para los cementerios Aborígenes de Arica.

Penetradores de espina de fauna marina. Se registraron 38 especímenes, probablemente correspondientes a la clase Chondryties (mantarraya). 
Fueron ofrendadas a un adulto masculino con momificación natural. Las espinas no están modificadas, su forma anatómica muestra un extremo redondeado y el otro aguzado, con los bordes laterales aserrados (Figura 13). Tienen entre 5,8 a 9 $\mathrm{cm}$ de largo y un diámetro basal de $0,7 \mathrm{~cm}$; y las pintaron de ocre. Un registro similar se encontró en el conchal de Quiani (Bird 1943), y en el campamento de pescadores de Ostra en el norte de Perú, fechado entre ca. 5.400-6.250 a.p. (Daniel Sandweiss, comunicación personal).

\section{Especímenes usados para un probable uso de sicotrópicos}

Espátulas. Se encontraron tres ejemplares, de diáfisis cortadas de ave. Los extremos fueron pulidos hasta darle una forma aguzada y/o redondeada (Figura 14a), sólo un caso presenta un rebaje oblicuo. Tienen entre 17,8 a $25 \mathrm{~cm}$ de largo por 1 a 2 $\mathrm{cm}$ de diámetros respectivamente. Se asocian a dos individuos: un neonato con momificación natural y un adulto femenino con pátina de arena, con dataciones posteriores a los ca. 3.800 a.p. El otro espécimen se ubicó en un área removida del sitio (sector T-27).

Tableta. Se encontró un fragmento de tableta de madera, en la superficie del sector T-22 del sitio. De forma rectangular y levemente socavada, sin ningún tipo de decoración (Figura 14b). Tiene un largo de 13,2 cm y conserva 3,6 cm de ancho.

Tubo de hueso. Sólo se halló un ejemplar, elaborado en diáfisis de ave, de $15 \mathrm{~cm}$ largo por $1,5 \mathrm{~cm}$ de diámetro. En el extremo proximal se observa un rebaje oblicuo, y por debajo del borde tiene seis incisiones de puntos que rodean el eje del hueso. El extremo distal es de corte recto, embarrilado con cuerda vegetal y pintado con ocre. Se encontró asociado a un adulto joven (sexo indeterminado) con momificación natural (ca. 3.800 a.p.).

\section{Contenedores: bolsas y cubiletes de hueso}

Bolsas tubulares. Elaboradas en fibra de camélido (hilada y torcida) con la técnica del entrecruzamiento de un set de elementos (Figura 15a) (Ulloa 1974). Se hallaron tres ejemplares (entre 17 a $20 \mathrm{~cm}$ de largo por 10 a $12 \mathrm{~cm}$ de diámetro) y se asocian a un individuo con momificación natural y dos con pátina de arena (todos adultos masculinos). Una contenía tubos de huesos, barbas para arpones e hilados de fibra de camélido.

Bolsitas de cuero. Elaboradas en cuero de camélido y pieles de ave, en general se encuentran muy destruidas por lo que no es posible determinar su forma, son pequeñas (entre 4 a $8 \mathrm{~cm}$ de diámetros) y fueron cocidas con cuerdas de tendón. Sirvieron para almacenar pigmentos (manganeso y óxido de fierro) con los que pintaban los cuerpos y algunos artefactos. Se registraron 13 ejemplares, asociados a los tres patrones funerarios (de todas las edades y ambos sexos).

Tubos o cubiletes de hueso. Se registraron nueve especímenes, corresponden a pequeños recipientes o cubiletes elaborados en diáfisis de ave. Sus extremos fueron cortados en forma recta, otros están fragmentados, y algunos están sellados en los extremos con tapones de piel de camélido y/o de ave marina (Figura 15b), con un largo entre 12 a $29 \mathrm{~cm}$, y un diámetro entre 1 a $2 \mathrm{~cm}$. Están asociados a individuos con momificación natural y con capa de arena (ambos sexos y todos adultos). Además de tres ejemplares sin asociación a cuerpos. Probablemente sirvieron para almacenar pigmentos de colores, ya que existen restos in situ.

\section{Objetos en materias primas vegetales}

Brochas. Se registraron ocho especímenes, y miden entre 7 a $21 \mathrm{~cm}$ de largo por 1 a $4,7 \mathrm{~cm}$ de diámetro, de sección circular. Se elaboraron a partir de "manojos" de fibra vegetal y embarrilaron un extremo o la sección medial con una cuerda vegetal y/o de cabello humano (Figura 16a). Un ejemplar tiene un madero eje para darle una mayor consistencia, y dos están pintadas de ocre. Están asociados a los tres patrones funerarios y se distribuyen en seis adultos, con cierta tendencia a ser más recurrentes en mujeres (tres mujeres, un hombre y dos de sexo indeterminado). Fueron usadas, entre otras funciones, en el pintado de los cuerpos $\mathrm{y}$ artefactos.

Cestería coiled. Se registraron tres evidencias, destacando su baja presencia. Un cesto (Figura 16b) contenía un feto humano con momificación natural, que fue inhumado sin cabeza y envuelto en un faldellín de fibra de camélido (ca. 3.700 a.p.). Los 


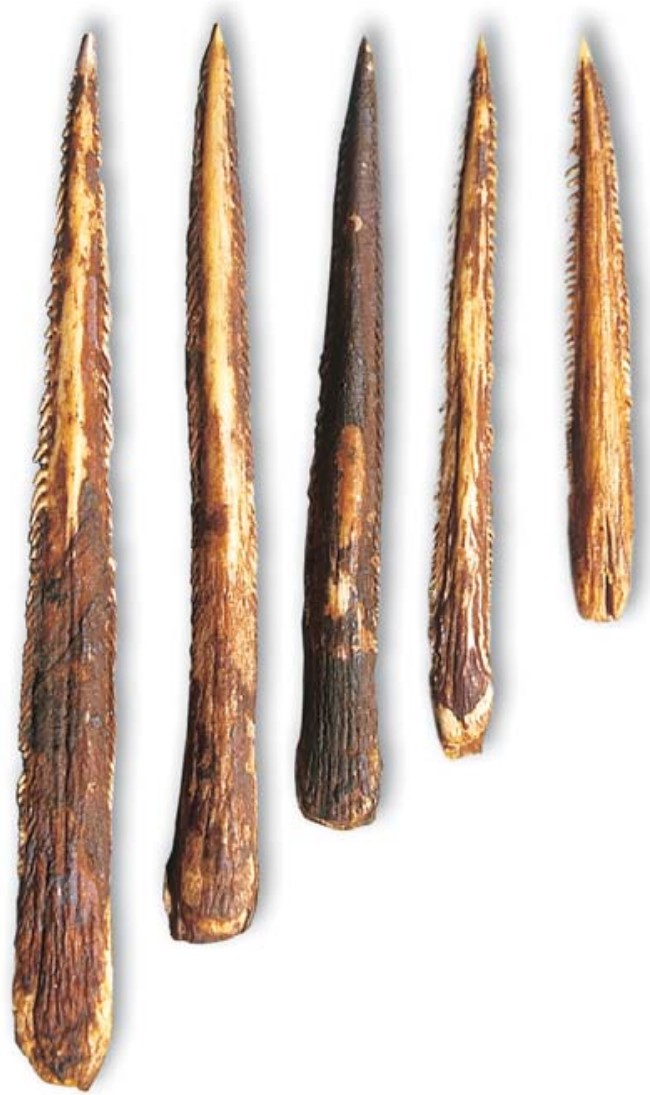

Figura 13. Penetradores de espina de fauna marina; posiblemente correspondientes a la clase Chondryties (mantarraya), (escala: $5 \mathrm{~cm}$ ).

Awls probably made of Chondryties sp. (stingray), (scale: $5 \mathrm{~cm}$ ).

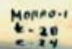

a)



b)

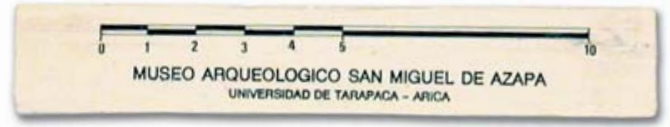

Figura 14. (a) espátula de hueso de ave; (b) tableta, fragmento, elaborado en mauer a uc iorma rectangular y levemente socavada, sin ningún tipo de decoración.

(a) bird bone spatula; (b) Fragment of a rectangular wooden tablet, with a slight depression, without decoration. 
dos restantes están asociados a un adulto masculino con momificación natural.

Esteras vegetales. Las esteras fueron muy populares, ya que suelen formar parte del fardo mortuorio de la mayoría de los individuos de los tres patrones funerarios. Elaboradas con la técnica de twining, las hay finas y gruesas, algunas con un bordado con fibra de camélido hilada y/o pelo humano, que forman diseños geométricos (Figura 17). En otras hay restos de pigmentos de coloración rojo, azul y negro que también forman diseños geométricos.

Aguja de espina vegetal. Pese a que debieron ser ampliamente usadas en la confección de bolsas, costura de fardos y la piel de las incisiones de los cuerpos por donde eran extraídos los órganos, y otras funciones; su presencia es mínima. Se registró sólo un especimen, de 7,5 cm de largo y 0,2 cm de diámetro, asociado a un adulto joven, masculino, con momificación natural.

Alfiler de espina vegetal. También se limita a un especimen, con 13,3 cm de largo con un promedio de $0,3 \mathrm{~cm}$ de diámetro, asociada a un adulto masculino, con momificación natural.

Yesqueros. Dos objetos de madera, de 75 y $40 \mathrm{~cm}$ de largo respectivamente por $1 \mathrm{~cm}$ de diámetro, son de sección circular, y presentan las típicas hendiduras circulares quemadas, como resultado de la fricción para generar chispa. Están asociados a un infante, masculino, con momificación artificial.

\section{Material misceláneo}

Maderos. Se registró gran cantidad de objetos de madera de diversos tamaños y grosores, algunos pintados y pulidos, usados en la preparación de los cuerpos con momificación artificial y en artefactos. Hay cinco especímenes de tamaño reducido, de sección circular, que fluctúan entre 12 a 33,5 $\mathrm{cm}$ de largo, fragmentados, con un diámetro entre 0,6 a $1 \mathrm{~cm}$; tienen un extremo aguzado y algunos están pintados con ocre. Están asociados a dos individuos con momificación natural (un adulto masculino y un feto) y uno con pátina de arena (adulto femenino); otros dos ubicados en sectores removidos del cementerio. Estos pudieron ser usados en trabajos de hilandería u otras funciones.

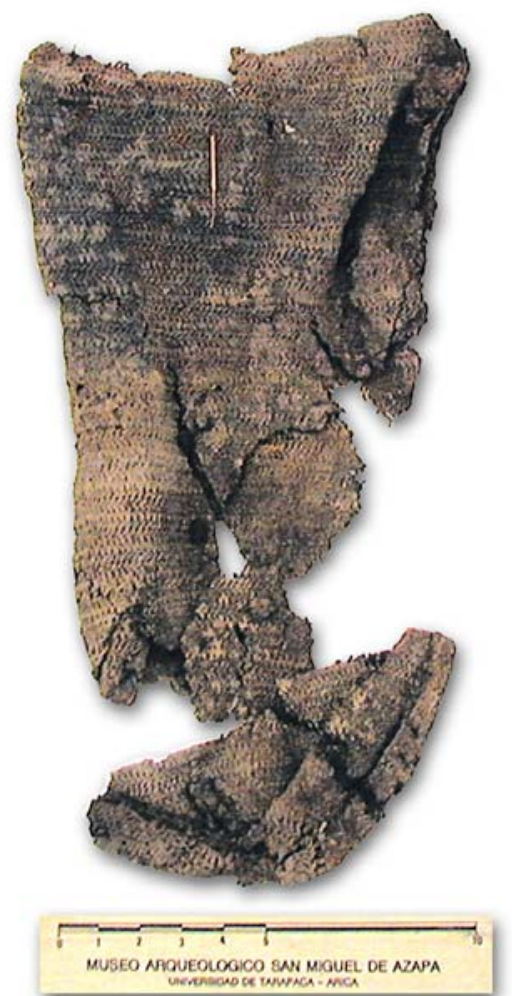

a)

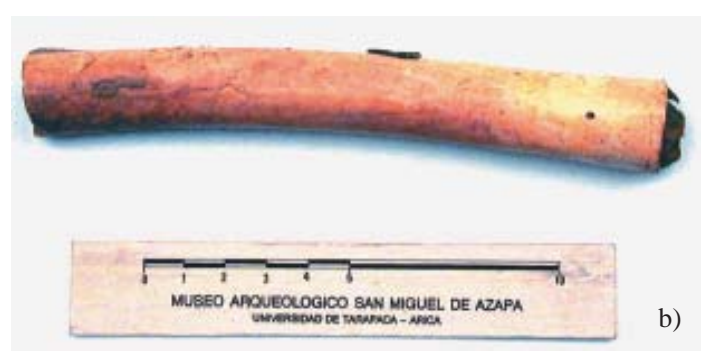

Figura 15. (a) bolsa tubular, en fibra de camélido con técnica de entrecruzamiento de un set de elementos; (b) tubo de hueso elaborado en diáfisis de ave marina, usado como recipiente o cubilete. Los extremos fueron cortados y sellados con tapones de piel de camélido y/o de ave marina (escala: $10 \mathrm{~cm}$ ).

(a) tubular bag made with camelid fiber in a single element looping structure; (b) bone tube manufactured from the diaphysis of a marine bird bone that was used as a container. The ends were cut and secured with camelid and/or marine bird skins (scale: $10 \mathrm{~cm}$ ).

Lima. Artefacto de arenisca, de forma rectangular $(10,6 \mathrm{~cm}$ de largo, $1,6 \mathrm{~cm}$ de ancho y $2 \mathrm{~cm}$ de grosor) probablemente con funciones de lima. Tiene pigmentos ocre adheridos, y está asociado a un neonato, de sexo indeterminado, con momificación natural. 

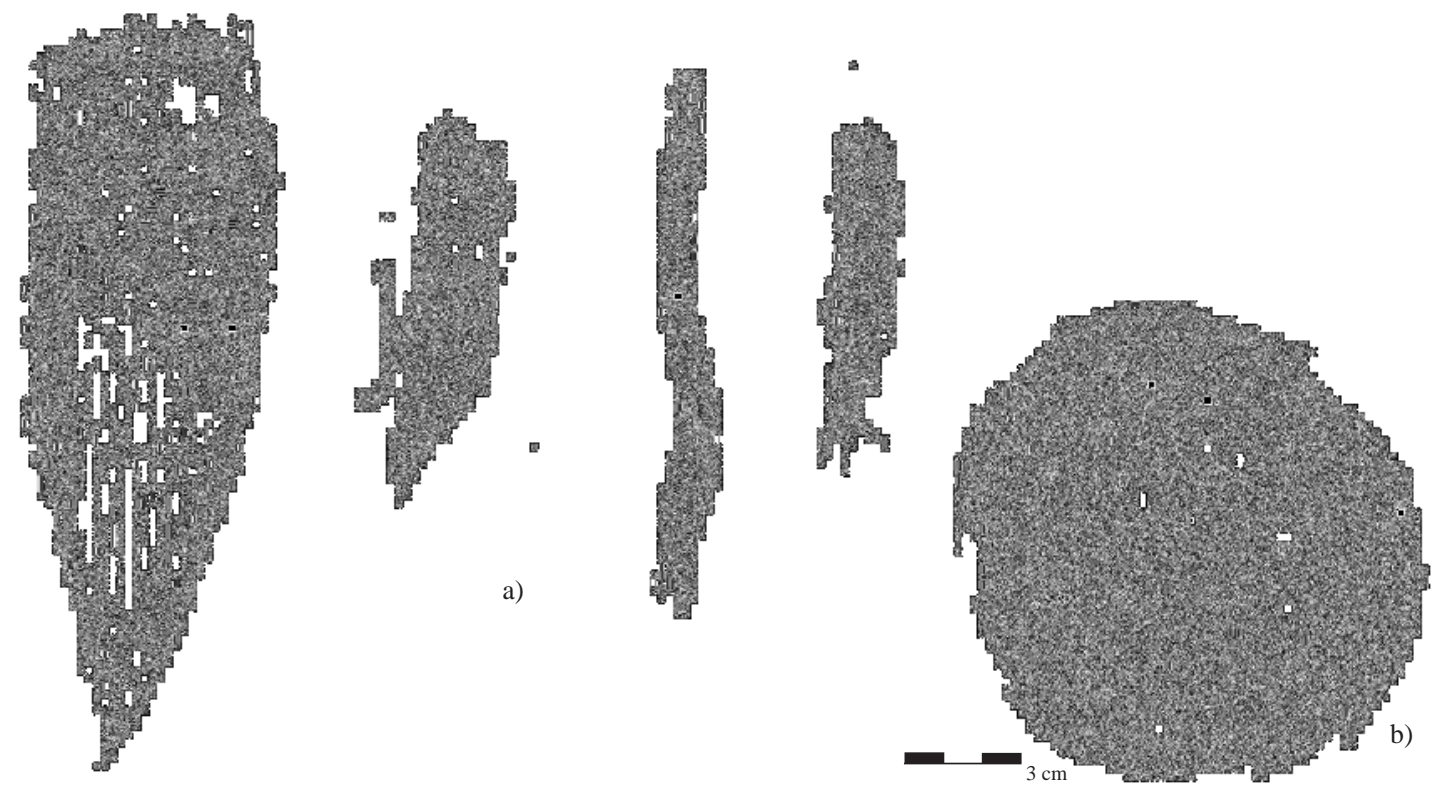

Figura 16. (a) brochas elaboradas a partir de "manojos" de fibra vegetal y embarrilauus en us exıremıs o sección medial con cuerda vegetal y/o de cabello humano. Un ejemplar tiene un maderito interno para darle una mayor consistencia, y dos están pintados de ocre; (b) cestería coiled.

(a) brushes made with clumps of vegetal fibers. One end of the brushes were wrapped with vegetal cords and/or human hair. One brush has an internal wooden stick to add extra support, and two brushes have remains of ocher paint; (b) coiled basketry.

Punzones de hueso. Se trata de dos piezas; una en diáfisis de ave, cuyo extremo manual está embarrilado con cuerda vegetal, mientras el otro extremo muestra huellas de uso en forma circular ascendente (Figura 18a), mide $17 \mathrm{~cm}$ de largo por 2 $\mathrm{cm}$ diámetro. Está asociado a un subadulto, de sexo indeterminado, con pátina de arena. El otro artefacto posee los mismos atributos que la vichuña actual, usada como apretador de trama en los períodos más tardíos, y por las tejedoras aymaras del norte de Chile. Tiene 18,4 cm de largo y está aguzado en el extremo distal (Figura 18b). Se encontró en el área de relleno de un adulto masculino, con momificación natural (ca. 3.700 a.p.), pero no ofrendado directamente.

Hilados de fibra de camélido. Gran número de hilados forman cuerdas de variados grosores (desde 0,2 $\mathrm{cm}$ a cordones de 3,0 $\mathrm{cm}$ de grosor). Estos debieron haber formado parte de una diversidad de elementos como: faldellines, cintillos cefálicos, decorado de esteras, y embarrilado de artefactos y momias.

Tortero. Elaborado en hueso, de forma acampanada, con un orificio central para introducir el made- ro, tiene $2,8 \mathrm{~cm}$ de alto por $2,6 \mathrm{~cm}$ de diámetro. $\mathrm{Se}$ ubicó la en superficie del sitio.

\section{Restos Faunísticos}

Se cuantificaron los restos faunísticos ofrendados a los individuos y se describen de acuerdo a su origen costero-marítimo o extracostero.

\section{Evidencias costero-marítimas}

Estos consisten en una variedad de especies como moluscos, crustáceos, algas, peces, mamíferos y aves marinas (Tablas 5 y 6 ), asociadas tanto a los individuos con momificación natural y los con pátina de arena; la excepción la constituyen una inhumación colectiva de momias negras (M1T1) asociadas a huesos de ballena, y una inhumación individual con momificación artificial simple, sellada con huesos de lobo marino, ballena, peces y conchas (M1T10B).

Moluscos. La especie más frecuente es Concholepas seguida de Choromitylus. Los choritos, almejas y lapas tuvieron una importancia ritual y 

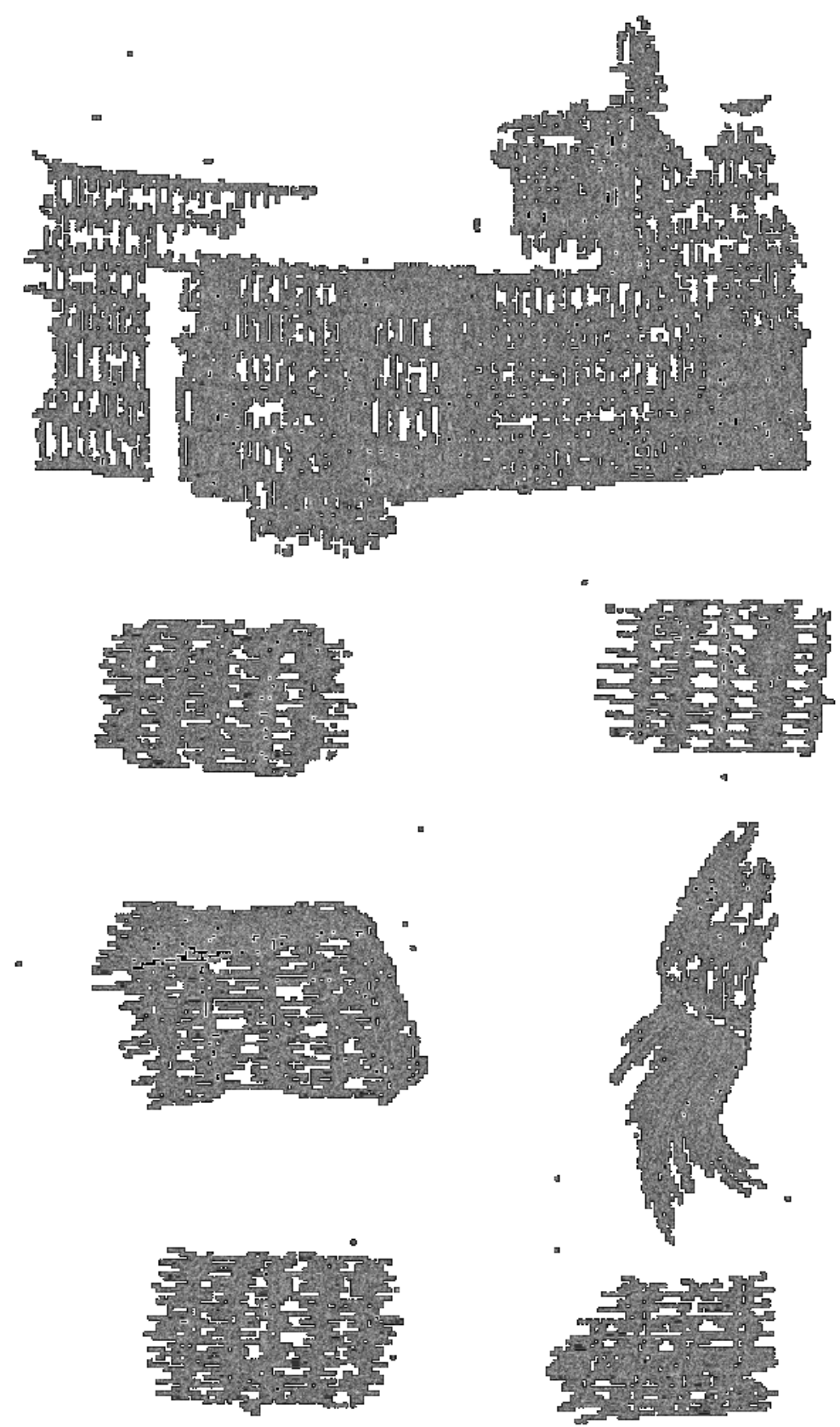

Figura 17. Esteras vegetales, pintadas y bordadas con fibra de camélido y cabello humano, (escala 1:1).

Vegetal fiber mats, painted and decorated with camelid fibers and human hair, (scale 1:1).

económica menor (Tabla 5). Su distribución es coherente con otros registros de la secuencia arcaica, tanto de conchales como de sitios de habitación. En el campamento Acha 2 se observó una mayor popularidad de Concholepas, entre otras especies
(Vilaxa y Corrales 1993:86). En Camarones 14, predominan también Concholepas y Choromitylus (Schiappacasse y Niemeyer 1984:78-79). En Tiliviche $1 \mathrm{~b}$, a $40 \mathrm{~km}$ al interior de la costa, tanto en las áreas de campamento como en el cemente- 
Tabla 5. Registro de moluscos del sitio Morro 1.

Frequency and proportion of mollusk, site Morro 1.

\begin{tabular}{lrrc}
\hline $\begin{array}{l}\text { Moluscos } \\
\text { Gastrópodos }\end{array}$ & $\mathrm{nmi}$ & $\%$ & Nombre común \\
\hline $\begin{array}{l}\text { Concholepas concholepas } \\
\text { Thais chocolata }\end{array}$ & 43 & 47,8 & $\begin{array}{c}\text { loco } \\
\text { Fissurella sp. }\end{array}$ \\
no identificadas & 1 & 1,1 & $\begin{array}{c}\text { locate } \\
\text { lapa }\end{array}$ \\
\hline Bivalvos* & 3 & 3,3 & señorita? \\
\hline Choromitylus choro & 25 & 27,8 & choro \\
Perumitylus purpurata & 3 & 3,3 & chorito \\
Mulinia sp. & 2 & 2,2 & almeja \\
\hline Total & 78 & $100 \%$ & \\
\hline
\end{tabular}

nmi: Número mínimo de individuos.

* Se cuantificó un ejemplar por dos valvas.

Tabla 6. Cuantificación de restos óseos de animales del sitio Morro 1.

Cuantification of remains of animal somes, site Morro 1.

\begin{tabular}{lcr}
\hline Huesos & Número & nmi \\
\hline Peces & 50 & 26 \\
Aves & 39 & 8 \\
Otaria & $11 *$ & 2 \\
Camélidos & $7 *$ & 1 \\
Cetáceos & 5 & 1 \\
Roedeores & 3 & 1 \\
\hline Total & 97 & 39 \\
\hline
\end{tabular}

* Incluidos los artefactos.

nmi: Número mínimo de individuos.

rio, también de ancestro costeño, aparecen Concholepas y Choromitylus, además de Fissurella sp., Oliva peruviana y caracoles blancos (Natica sp.) como elementos de adorno (Núñez y Hall 1982; Standen y Núñez 1984). En toda la secuencia de Quiani hay predominio de Concholepas y Choromitylus (Bird 1943); lo mismo vale para Quiani 9 (Muñoz y Chacama 1982). Esto podría indicar que durante todo el Arcaico (9.000-3.700 a.p.) la parte de la dieta consistente en moluscos no sufrió grandes cambios, siendo locos y choros los moluscos dominantes, tanto para su consumo como para actividades rituales.
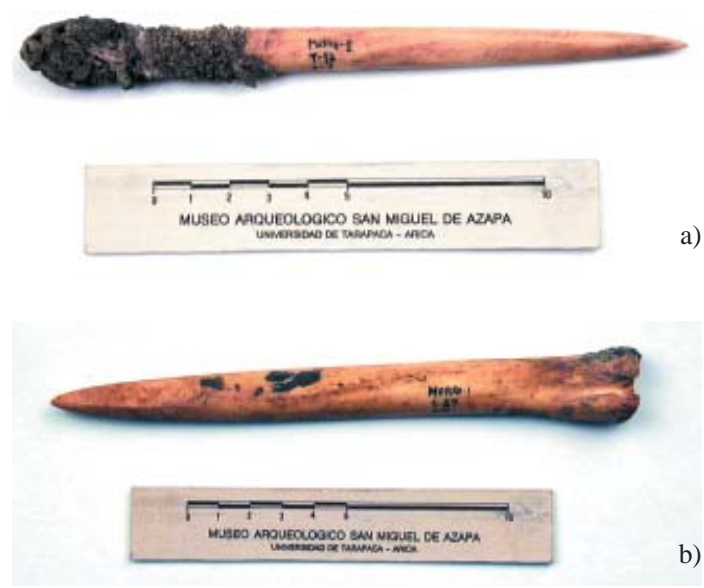

Figura 18. (a) punzón de hueso, elaborado en diáfisis de ave; (b) artefacto de hueso de similares características a los usados como apretador de trama en los períodos más tardíos (vichuñas), y por las tejedoras Aymara del norte de Chile.

(a) bird bone awl; (b) bone instrument similar to those used as shed sticks for looms in later cultural periods (vichunas), and by present day Aymara weavers of northern Chile.

Crustáceos. Se encontraron sólo dos pereiópodos (extremidades) y un exoesqueleto. Están presentes en Camarones 14 (Schiappacasse y Niemeyer 1984) y Quiani (Bird 1943) también en cantidad mínima.

Algas. Se identificaron solo tres fragmentos pequeños, correspondientes a Macrocystis sp. Sólo Schiappacasse y Niemeyer (1984:84) señalan su escasa presencia en Camarones 14, y no se mencionan para otros sitios arcaicos. Fueron usadas como relleno, al menos en un individuo con momificación artificial del estilo rojo, y probablemente como combustible.

Peces. No ha sido posible identificar las especies a la que correspondan los restos óseos recuperados en el sitio, a excepción de 20 peces pequeños que parecen corresponder a sardinas. Las porciones óseas que se registran corresponden a cráneos y vértebras, más una aleta caudal de presa grande que conserva tejido blando y está embarrilada con cuerda vegetal. La cuantificación total, entre los asociados a individuos y los registrados en sectores removidos, corresponde a: 20 peces (probablemente sardinas); 22 vértebras; dos huesos planos y una aleta caudal (no identificadas). 
Mamíferos marinos. Se hallaron costillas y escápulas de lobo marino y cetáceos, asociadas a dos inhumaciones: una individual de una mujer adulta, con incipiente momificación artificial (T10B) y una colectiva de momias del estilo negro (M1T1).

Aves marinas. Corresponden probablemente a pelícanos, y se ubicaron: 13 picos, 11 huesos de extremidades y dos cráneos; además de las pieles usadas en la preparación de los fardos funerarios, lo cual sugiere una captura intensiva. Algunos cráneos y huesos largos fueron pintados de ocre y depositados como ofrendas. Se registran también huesos pulidos como cubiletes o recipientes, espátulas y un tubo. Los picos de pelícanos pintados con ocre (Figura 19) pudieron ser usados como bisturíes para cortar las pieles en el proceso de la momificación artificial, aunque no se constata una clara asociación a los individuos con momificación artificial.

Las aves debieron constituir un aporte importante en la dieta; el registro en general muestra un uso integral (pieles y huesos), y cierta orientación ritual de algunas partes del esqueleto. Registros etnográficos e históricos demuestran que entre los Kaweskar (habitantes de los archipiélagos del extremo sur) las aves junto a los mamíferos marinos y peces constituían el recurso básico de la dieta (Chapman 1988; Emperaire 1963).

\section{Evidencias extracosteras}

En general, no se identificaron evidencias del interior; sólo se encontraron un fragmento de costilla, una falange y un casco (pezuña) de camélido, más tres huesos de roedor. Esta fauna tuvo su hábitat tanto en la costa como de las quebradas interiores. La excepción corresponde a una piel de ñandú, identificada por técnica inmunológica, que formaba parte de la envoltura externa de un individuo con momificación artificial estilo negro. Este registro es relevante ya que estas aves son muy territoriales y en el norte de Chile no se encuentran en alturas inferiores a los $3.000 \mathrm{msm}$. Por ende, este es el único registro claramente extracosteño, procedente desde las tierras altas andinas.

\section{Dieta, Subsistencia, Economía y Bienes Funerarios}

Entre los restos faunísticos del sitio Morro 1, son los moluscos Concholepas y Choromitylus los que muestran mayor popularidad (Tabla 5), lo cual es válido para los sitios de vivienda, conchales y cementerios de todos los sitios arcaicos, tanto de la costa como del interior, a excepción del campamento de Acha 2, donde Mesodesma tiene también una alta representación. Además, las conchas, especialmente locos y choros, fueron reutilizadas como depósitos para pintura, elaboración de cuentas para collares y pendientes, y probablemente como contenedores de alimentos.

El registro de peces es menor (Tabla 6) consiste de sardinas completas (20 ejemplares ofrendados a un individuo) y otros huesos pequeños, lo cual concuerda con un bajo registro de anzuelos (solo seis ejemplares). El tercer rubro corresponde a aves, que a juzgar por la evidencia representarían un número mayor de ejemplares, ya que se integran pieles, cubiletes y espátulas de huesos. La cuarta posición corresponde a mamíferos marinos, con predominio de lobo marino; a pesar de la baja presencia ósea, la alta proporción de cabezales de arpón para la caza y la reutilización de los subproductos como los huesos de costillas para la elaboración de artefactos (v.gr. chopes) más el uso del cuero en los fardos, indican que su captura pudo ser prioritaria, a raíz de su mayor biomasa y riqueza dietética. En contraste, el consumo de cetáceos debió darse cuando éstos varaban en forma ocasional en la costa, tal como sucedía entre los Selknam en Tierra del Fuego (Gusinde 1982).

La presencia ósea de camélidos es mínima (Tabla 6), tanto en forma de desecho alimenticio como de artefactos elaborados. Esta observación es válida para todos los conchales y campamentos arcaicos excavados en costa y en el interior cercano. En Camarones 14 se registran 92 huesos de lobo marino y solo tres de camélido (Schiappacasse y Niemeyer 1984:73), en Quiani 9 (Muñoz y Chacama 1982:66) y en Punta Pichalo (Bird 1943:273) no se registran huesos de camélidos, a pesar del gran volumen excavado en el último sitio. Incluso Bird sugiere que, si los camélidos fueron consumidos, esta actividad no se realizó en el campamento. En su excavación de Quiani (Bird 1943) tampoco menciona camélidos. En Tiliviche 1b, no supera el 3\% del total de los desperdicios analiza- 


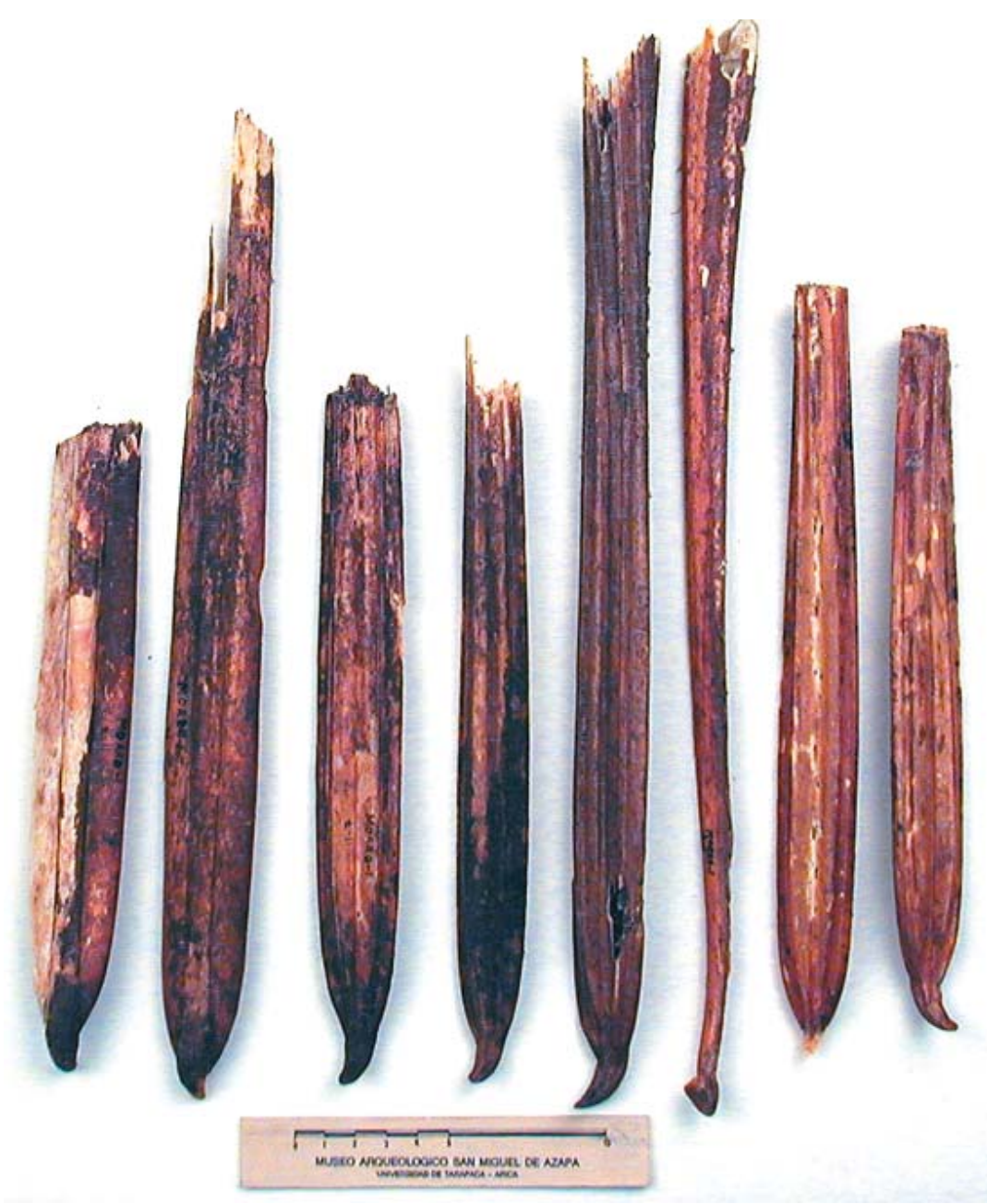

Figura 19. Picos de pelícanos, pintados de ocre (escala: $10 \mathrm{~cm}$ ). Pelican beaks painted with ocher (scale: $10 \mathrm{~cm}$ ).

dos (Núñez y Moragas 1977-78:57), lo que demuestra una mínima presencia, aun en ambientes de oasis alejados de la costa. En Acha 2 (Muñoz et al. 1993) tampoco hay registro óseo de camélidos en el efímero depósito del campamento. Sin embargo, en las inmediaciones de la terraza identifican restos de coprolitos, aunque no puede establecerse una correlación cronológica estricta con el campamento. La excepción la constituye Camarones 17, donde ubican coprolitos de camélido (Muñoz et al. 1993), aunque podrían ser resultado de una depositación secundaria.

Por otro lado, Aufderheide $(1993,1996)$ ha realizado análisis químicos para la cuantificación de ciertos metales traza (estroncio) y la proporción de isótopos (carbono, nitrógeno y azufre) en mues- tras óseas humanas, con el objeto de reconstruir patrones dietéticos entre las poblaciones prehispánicas. Estos indican que en las poblaciones arcaicas de la zona de Arica la fracción marina de la dieta fue dominante (sobre el $80 \%$ ) y la proteína de origen animal era obtenida básicamente del lobo marino. En contraste, la fracción vegetal y el consumo de fauna terrestre no superaron el $20 \%$ respectivamente.

Así, la información cuantitativa de los restos de alimentos provenientes de conchales y cementerios, más los análisis químicos de los huesos, hablan de un muy bajo consumo de camélidos por parte de los cazadores y pescadores arcaicos del litoral de Arica. Esta situación contrasta con la alta presencia en el sitio Morro 1 de pieles de camélidos 
utilizadas en los fardos funerarios, además del uso intensivo de la fibra hilada y torcida, en: faldellines, cintillos cefálicos, decorado de esteras, embarrilado de artefactos y cordelería diversa; además del vellón usado como relleno de cuerpos con momificación artificial, los que dan cuenta de un uso bastante más importante que lo que se presenta en la Tabla 6. Tampoco se observa una reutilización más integral del subproducto óseo de la caza. En general, la elaboración de artefactos óseos es mínima y contrasta con la alta proporción de objetos elaborados en madera. Finalmente, el escaso consumo de carne de camélido por estos grupos humanos, demostrado a través del análisis químico de los huesos, avalarían la hipótesis de que el acceso a la captura de esta fauna no era realizada en forma directa por los cazadores, pescadores y recolectores costeños, y podrían haber obtenido el subproducto de las pieles y probablemente la fibra hilada, vía intercambio con cazadores de las quebradas y mesetas andinas, que por esa misma época se han documentado en las tierras altas de Arica (Santoro y Núñez 1987).

Por otro lado, los bienes funerarios (artefactos) podrían acercarnos a una mejor interpretación sobre ciertas estrategias en la apropiación de alimentos. Para este efecto se consideraron tres indicadores: los chopes o desconchadores de hueso, para mariscar y desconchar, tarea de recolección; los anzuelos, tarea de pesca; y los cabezales de arpón, tarea de caza. En cuanto a chopes, se identificaron nueve especímenes $(17,4 \%)$, seis anzuelos $(11,4 \%)$ y 37 cabezales de arpones $(71,1 \%)$. Así, cuantificando estos tres tipos de artefactos se podría sugerir que la actividad de caza de fauna marina habría sido prioritaria con relación a la recolecta y la pesca, a través de un predominio de las prácticas de arponeo. Por otro lado, la alta proporción de arpones en los contextos funerarios podría sugerir que esta actividad gozaba del más alto prestigio al interior del grupo; sin embargo, contrasta con la casi nula presencia de puntas de proyectil (solo tres). Esta situación podría explicarse por: (a) carencia de materias primas en la costa para la elaboración de artefactos líticos; (b) las puntas tenían un alto valor utilitario, por lo cual no eran depositadas junto a los difuntos; (c) las puntas eran heredadas a las nuevas generaciones por su alto valor simbólico; (d) el alto número de cuerpos disturbados junto a sus contextos, pudo alterar el registro real de puntas.
Finalmente, una de las importantes actividades económicas que falta en el registro arqueológico es la recolección de la fibra vegetal. A pesar que esta actividad debió también ser prioritaria, para lograr el abastecimiento requerido en una diversidad de artefactos y funciones de la vida cotidiana y rituales, no hemos identificado artefactos que pudieran ser asignados a la tarea de "recolección de la fibra vegetal", a excepción de un cuchillo lítico en la mano de una mujer adulta (preparada con pátina de arena).

\section{Discusión y Conclusiones}

\section{Los bienes funerarios: su contexto e interpretación}

En la Tabla 3 se detallan los 301 bienes funerarios excavados en el cementerio Morro 1. Estos se distribuyen en: (a) bienes utilizados en la explotación de los recursos marinos, para las tareas de caza, pesca y recolección, los cuales incluyen astiles, cabezales y barbas para arpones, anzuelos de espina vegetal y sedales para la pesca, pesas líticas, bolsas redes y desconchadores de moluscos $(\mathrm{n}=100)$; (b) bienes para vestirse y ornamentarse el cuerpo, incluye faldellines, cobertores púbicos, cintillos cefálicos, gorritos de pieles de ave, cuentas y pendientes de hueso, semilla y piedra $(\mathrm{n}=86)$; (c) bienes para las tareas de la caza terrestre, incluye: estólicas, dardos, lanzas y arcos? $(\mathrm{n}=22)$; (d) contenedores como bolsas de fibra de camélido, cuero y cubiletes de diáfisis de ave $(\mathrm{n}=23)$; además se registran artefactos únicos o escasos, con diversas funciones como: punzón y lezna de hueso, lima de arenisca, cuchillo enmangado, hoja lítica con funciones cortantes, alfiler y aguja vegetal, yesqueros, cestería coiled y cuatro lajas líticas. Es notable la mínima presencia de puntas líticas de proyectil (solo tres), además de 38 penetrados de mantarraya, estos últimos ofrendados a un solo individuo. Se registraron además escasos elementos que pueden relacionarse con el probable uso de sicotrópicos: un tubo, una tableta y tres espátulas de hueso, asociados a individuos con momificación natural y con capa de arena, con dataciones posteriores a los 3.800 a.p., y en superficie, como la tableta. Lo mismo sucede con una faja de fibra de camélido elaborada en telar de cintura asociada a un cuerpo con pátina de arena, y un artefacto de hueso usado probablemente en trabajos de 
hilandería, registrado en la superficie del sitio y probablemente intrusivo.

La cuantificación de los bienes funerarios mostraría ciertas tendencias. Primero, que las actividades de subsistencia estuvieron básicamente orientadas a la explotación de los recursos marinos, tanto por la presencia de artefactos como por los restos faunísticos asociados a los cuerpos. Esta orientación hacia los recursos marinos se ve avalada además por la alta presencia de exostosis auditiva externa (30\%) en la población adulta masculina del sitio Morro 1 (Standen et al. 1996). Este rasgo se ha identificado exclusivamente en poblaciones que habitaron ambientes costeros junto al mar, y lo relacionamos con actividades de inmersión, como el buceo, que practicaron las poblaciones probablemente para ampliar su fuente de subsistencia. Además los estudios de paleodieta (Aufderheide 1993, 1996) indican un alto consumo de alimentos de origen marino, que constituyen más del $80 \%$ de la dieta. Entre las tareas como la caza, la pesca o la recolección, es clara la mayor cantidad de artefactos vinculados con las prácticas de caza, en oposición a las actividades de pesca y recolección. ¿Fue la caza una de las actividades económicas y sociales de mayor prestigio al interior de los grupos chinchorro?

Otra tendencia observada, es que las mujeres muestran más artefactos de pesca asociados (anzuelos, pesas y sedales) en comparación a los hombres. De mantenerse esta tendencia en otros cementerios, cierta relación entre las actividades de pesca y las mujeres podría sugerirse. Contrariamente hay más hombres con bienes asociados como astiles y barbas para arpones (actividades de caza marina), aunque esta relación no se da para los cabezales de arpón, ya que se encuentran asociados a ambos sexos y todas las edades. ¿La tendencia a depositar ciertos artefactos de caza asociada a los hombres, y los artefactos de pesca en mujeres y niños, se vincularía con actividades realizadas bajo un orden social respecto a los roles sexuales de los individuos al interior de la sociedad chinchorro? Hay inhumaciones de mujeres que indicarían cierta jerarquía, por ejemplo, una (M1T10B) muestra abundantes ofrendas de huesos de cetáceos, lobo marino, peces y conchas, otra (M1T8) tuvo abundantes peces pequeños, probablemente sardinas secas ofrendadas. Podría sugerirse una diferenciación sexual en los patrones de tareas de actividades marinas y patrones de conducta y organización social. Esto lo hemos observado más claramente desde el análisis de dos marcadores óseos: la exostosis auditiva externa, generada por prácticas de buceo y los traumas y signos de violencia. Ambos marcadores muestran una mayor presencia en los hombres adultos (Standen et al. 1996; Standen y Arriaza 2000).

Cuando se analiza la asociación de bienes funerarios con el tipo de tratamiento de los individuos, es claro que son los con momificación natural los que presentan mayor cantidad y diversidad (Tablas 3 y 4), aunque porcentualmente no difieren de los individuos con pátina de arena: 2,3 y 2,1 ítem por individuo respectivamente (Tabla 7). A diferencia de los cuerpos con momificación artificial que alcanzan solo 0,6 ítem por individuo. Estas diferencias muestran una clara tendencia a que a los individuos con momificación artificial les disponen escasos bienes funerarios al momento de ser inhumados.

En general, los bienes funerarios tienen en su mayoría antecedentes en los sitios costeros tempranos y del interior, como Acha 2 y 3, Tiliviche

Tabla 7. Relación entre bienes funerarios y tipos de tratamiento mortuorio, sitio Morro 1.

Ratio of number of items and number of bodies for each type of mortuory treatment.

\begin{tabular}{lccc}
\hline Tipos de tratamiento & $\mathrm{N}^{\text {o }}$ de cuerpos & $\mathrm{N}^{\text {o }}$ de ítemes & Ítem/Individuo \\
\hline Momificacion natural & 79 & 184 & 2,3 \\
Cuerpos con pátina de arena & 18 & 39 & 2,1 \\
Momificación artificial & 37 & 23 & 0,6 \\
Superficie y sectores removidos & 0 & 55 & \\
\hline Total & 134 & 301 & \\
\hline
\end{tabular}

n: Número. 
1b, Camarones 14 y 17, Quiani 1 y 9, Punta Pichalo (Bird 1943; Muñoz y Chacama 1982; Muñoz et al. 1993; Núñez 1989; Schiappacasse y Niemeyer 1984; Standen y Santoro 1997). Son pocos los artefactos innovadores que se registran en el sitio, y éstos se asocian exclusivamente a individuos con momificación natural, con dataciones posteriores a los 3.800 a.p., y corresponden a: bolsas tubulares de fibra de camélido; espátulas y tubo de hueso; pendientes de concha, huesos y semillas; probable apretador de trama y faja de lana tejida en telar de cintura; cestería espiral; esteras bordadas con diseños geométricos, y los siempre polémicos arcos.

La vestimenta es otro de los rasgos conservadores que perdura por casi 4.000 años entre los cazadores recolectores y pescadores del desierto costero. Esta se caracteriza por el uso de faldellines, y en menor popularidad los cobertores púbicos, de fibra vegetal y fibra de camélido. Por los 3.800 a.p. se elaboran faldellines de fibra de camélido con dualidad de colores (tonalidades de café) y técnicas más complejas. La tradición del uso del faldellín viene desde Camarones 14 (7.000 a.p.), donde en el conchal se registró un fragmento (Schiappacasse y Niemeyer 1984:67) aunque no tenían por costumbre aún vestir a los difuntos con este elemento, como en los milenios posteriores, tan populares en el Morro 1 y los "Aborígenes de Arica" (Uhle 1919). Bird (1943:245) también los describe en los cuerpos del conchal de Quiani; y Muñoz y Chacama (1982: Figura 8) los encuentran en La Capilla, donde ubicaron 23 faldellines vegetales bajo el piso de ocupación, y les asignan un valor simbólico vinculado a ritos de iniciación. El carácter simbólico también se evidencia en el sitio Morro 1, donde un mismo cuerpo presenta hasta tres faldellines, de los cuales algunos están sin uso. El hallazgo de un feto humano envuelto en dos faldellines de adulto, sin uso, indica que fueron elaborados especialmente para el rito mortuorio. Los cobertores púbicos fueron menos populares pero también se encuentran en los cementerios arcaicos; Muñoz y Chacama (1982) describen unos paños pequeños de forma rectangular elaborados en fibra vegetal con técnica de twining, que le asignan esta función, en La Capilla. En el Morro 1 se observa cierta tendencia a que los faldellines están asociados a mujeres y los cobertores púbicos a los hombres.

Entre los artefactos de caza, los cabezales de arpón son extraordinariamente populares $(\mathrm{n}=37)$, le siguen las lanzas $(n=6)$ y estólicas $(n=5)$. Las estólicas se han registrado en los cementerios chinchorro (Núñez 1963; Rivera y Zlatar 1982) de Patillos, Caleta Huelén 42, Quiani (Bird 1943:240241-245), Morro de Arica (Munizaga 1964) y Aborígenes de Arica (Uhle 1919). En una momia procedente de Patillos se encontró una estólica al interior de un cuerpo con momificación artificial (Rivera y Zlatar 1982). En el sitio Morro 1, la estólica más temprana está asociada a un cuerpo con momificación artificial estilo negro, datado a los 5.130 a.p. (puesta externamente paralela a la extremidad superior derecha).

\section{Relaciones de intercambio entre los grupos chinchorros con los cazadores altoandinos}

Se propone, a modo de hipótesis, que los pueblos costeros habrían mantenido cierto tipo de relaciones de intercambio económico y social con bandas de cazadores andinos de camélidos, quienes habrían aportado con pieles y vellones de vicuñas y/o guanacos. Si los chinchorros hubieran cazado los guanacos en la costa, es significativo el hecho que no realizaran un aprovechamiento más integral de todos los recursos, ya sea con fines alimenticios, o como materia prima para elaborar artefactos u otros bienes. En efecto, la industria ósea sobre hueso es mínima en el sitio, así como en los campamentos y conchales arcaicos. La recurrencia de los artefactos está dada principalmente en aquellos necesarios para la explotación del litoral y elaborados con materias primas locales, básicamente maderas y fibra vegetal. Por otro lado, los análisis de paleodieta reflejan un muy bajo consumo de proteína animal de origen terrestre, de sólo un $10 \%$, que contrasta con la altísima fracción de proteína animal de origen marino, que cubre más del $80 \%$ de la dieta de las poblaciones chinchorro (Aufderheide 1996).

Estas eventuales relaciones de intercambio se apoyarían además en el registro de piel de ñandú (Pterocnemia sp.) identificada por análisis inmunológico, en un cuerpo con momificación artificial del sitio Morro 1 (T1/C4) (informe de J. Löwestein 1984). Este dato es de importancia, ya que esta fauna se encuentra en cotas sobre los $3.000 \mathrm{msm}$ al menos en el norte de Chile. Por otro lado, Schiappacasse y Niemeyer (1984:74) identificaron pieles de vicuña en Camarones 14. Nandúes y vicuñas, ambas especies territoriales, ya estaban 
incorporadas a la economía de los cazadores andinos por esa misma época (Santoro y Núñez 1987) y ciertos subproductos, como las pieles con su vellón, se habrían constituido en un importante excedente económico para intercambiar con los pueblos de cazadores y pescadores de la costa del Pacífico sur, quienes habrían aportado con pescados secos y conchas de moluscos.

\section{¿Está el arco asociado a chinchorro?}

Bittmann y Munizaga (1979), Rivera (1975), Rivera y Rothhammer (1986), Uhle (1917, 1919) han asociado el arco a chinchorro. Fue Uhle (1919) quien primero argumentó haber encontrado un par de arcos en los cementerios aborígenes de Arica:

\section{Arco de madera dura, al parecer algarro- bo; fue encontrado en tres pedazos, en el interior de una momia, aderezada por la introducción de palitos de diferentes cla- ses. Su corte transversal es un óvalo chato, en sus proporciones muy parecido a los usados en el río Ucayali, y a otros ríos del Este, pero diferente de aquellos, porque termina, por un lado, en forma obtusa y, por el otro, adelgazado y más apuntado, sin existencia de hombros que pudieran su- jetar fácilmente la cuerda (Uhle 1919:7).}

Fragmento de un arco más débil y más corto, de corte transversal redondo (Uhle 1919:16).

Sin embargo, en ninguno de los sitios arcaicos tanto de la costa como del interior se han registrado evidencias de arcos (Álvarez 1969; Bird 1943, 1946; Muñoz y Chacama 1982, 1993; Núñez 1989; Schiappacasse y Niemeyer 1984; Standen y Núñez 1984; Standen y Santoro 1997; Santoro y Núñez 1987). Con relación a la industria lítica, no hay registros de puntas de flechas. Aunque Bird (1943:240) describe unas puntas triangulares pequeñas, las registra sólo en la superficie del conchal de Quiani. En este contexto, Bittmann y Munizaga (1979) sostienen que el arco chinchorro correspondería a la evidencia más temprana que se conoce en América:

Se dispone atravesando el cuerpo en sentido longitudinal desde la pierna izquier- da a través del tronco y del cuello y entrando en el cráneo... Tiene un largo total de $144 \mathrm{~cm}$ con sección redonda o levemente ovalada de $1.5 \mathrm{~cm}$ diámetro máximo... con forma de bisel en uno de sus extremos. El otro está quebrado, sin duda intencionalmente.... la forma central del arco está levemente curvada mientras que sus extremos toman la forma de hombros recurvados... El largo total debió ser 155 cm (Bittmann y Munizaga 1979:236).

Estos autores sostienen que no corresponde a los descritos por Uhle (1919) y dudan de una supuesta procedencia altiplánica o amazónica. Por su parte, Rivera (1975), y Rivera y Rothhammer (1986) plantean que el arco se asocia a la última fase de la llamada "Tradición Chinchorro", más puntualmente a lo reconocido por Rivera como "Chinchorroide" (1975). Este autor considera las evidencias de Playa Miller 7 (ca. 500 a.C., Focacci 1974) y no incorpora los datos iniciales de Uhle. Posteriormente Rivera (1986) considera el arco y la flecha como rasgos diagnósticos de su Fase II de chinchorro situándolo cronológicamente entre $\operatorname{los} 3.500$ y 2.000 a.C., aunque no se conoce ningún registro de arco, fechado en ese tiempo. También Núñez (1969) considera el registro del arco de Uhle como dudoso. Concretamente las únicas evidencias de los supuestos arcos en contextos chinchorro corresponden a los dos descritos por Uhle (1919) y uno por Bittmann y Munizaga (1979).

En el sitio Morro 1 se registraron: (a) maderos levemente curvados, de consistencia dura y resistente, con los extremos algo aguzados, pero sin huellas de amarre del tensor. Si correspondieran efectivamente a arcos, se encuentran asociados a un individuo con momificación natural, con una datación posterior a los 3.800 a.p. y en áreas disturbadas; (b) maderos que se encontraban en el interior de los cuerpos con momificación artificial. El análisis de estos últimos no avala que pudieran corresponder a arcos (aunque obviamente no fueron observados todos los maderos, por razones de preservación del material). Son indistintamente largos o cortos, rectos o curvos, y algunos presentan huellas de embarrilado, ya que estaban amarrados a huesos de los esqueletos momificados. Los diámetros son variables $(3-5 \mathrm{~mm})$ y la madera es frágil, siendo de sección circular, ovoidal y/o planconvexo. Sólo un caso detectado en una mo- 
mia planteó algunas dudas, ya que los maderos que se habían introducido en las extremidades inferiores tenían ciertas características de arcos: $70 \mathrm{~cm}$ de largo, de sección ovoidal achatada (1,8 x 0,6 $\mathrm{cm}$ de diámetros) con ambos extremos aguzados y curvado en la parte central (Figura 10e). Pero al analizar la posición que tenían en el interior de la extremidad, se observó que la curvatura del madero se debió a la forma en que fue puesto desde el maléolo tibial (tobillo), luego se desliza por la cara posterior de la extremidad quedando presionado por la cara posterior de la pierna y asciende hasta la cadera para ubicarse por debajo del trocánter mayor del fémur. En las extremidades inferiores la musculatura fue extraída parcialmente, por lo que fue necesario agudizar el madero para permitir su deslizamiento y penetración; además, otros maderos más pequeños y rectos también presentan los extremos aguzados, como uno puesto paralelo a columna vertebral. Esto significaría que se está en presencia de un sistema de maderos cuidadosamente elaborados, destinados al reforzamiento de la estructura ósea del cuerpo, más que a arcos.

\section{Acumulación y excedentes}

El análisis de los contextos mortuorios, las prácticas de la momificación artificial y la elaboración de fardos funerarios reflejan una clara tendencia a la acumulación, algo más bien atípico entre los cazadores recolectores (Sahlins 1985). Aunque Binford (1980) al caracterizar a los "collectors" sostiene que ciertos grupos acumulan básicamente alimentos, determinado por una fuerte estacionalidad de los recursos de subsistencia. Binford (1980) plantea el aspecto de la acumulación, básicamente en función de los recursos alimenticios y no de las materias primas.

Los chinchorros fueron expertos en explotar las zonas pantanosas y húmedas de los cursos de agua de los valles, donde prolifera la típica flora de totorales y junquillos (Equisetum y Scirpus). La explotación de los totorales para extraer las plantas acuáticas de uso económico y ceremonial, las cuales fueron decisivas en todas las esferas de la vida de los chinchorros: elaboración de esteras para sus habitaciones y cobertores para dormir; fabricación de sedales para la pesca y el embarrilado de chopes y arpones; confección de bolsas; vestimentas y ornamentos corporales, como los faldellines y cintillos cefálicos; esteras usadas en los fardos funerarios y relleno de los cuerpos con momificación artificial. Así la materia prima que acumularon por excelencia fue la fibra vegetal, la que se advierte en el intensivo uso de ésta en una diversidad de elementos, por lo que debió estar permanentemente disponible. Almacenaron también las pieles de camélidos para ser usadas como parte del fardo funerario y la fibra o vellón, que era requerida como materia prima para la confección de faldellines, bordados de esteras, cintillos cefálicos, embarrilados de artefactos, además en el relleno de los cuerpos con momificación artificial.

La costumbre de depositar bienes funerarios junto a los difuntos es otro aspecto particular. Esta práctica coincide con cambios en los patrones mortuorios, los que reflejarían cambios ideológicos y en la concepción religiosa de estos pueblos. Por otro lado, indicaría cierto sentido de propiedad de los bienes, probablemente heredados, ya que hay lactantes con chopes y anzuelos, los cuales difícilmente pudieron haber sido usados por los individuos a los cuales se los ofrendaron.

\section{Los orígenes biológicos y el desarrollo cultural}

Rivera (1975), y Rivera y Rothhammer (1986, 1991) han sostenido que chinchorro se habría derivado de flujos migratorios de origen amazónico, tanto en su expresión cultural como en la filogenia de las poblaciones humanas. Como hipótesis alternativa, se ha sugerido que chinchorro, como expresión fenomenológica, correspondería a un proceso de desarrollo local de las poblaciones que habitaron el desierto costero chileno- peruano desde hace unos 9.000 años (Arriaza 1995; Guillén 1992; Standen 1991; Núñez 1999), aunque sus ancestros biológicos se encuentren en la floresta tropical.

Para sostener el origen amazónico se han considerado indicadores tales como: (a) equipamiento para inhalación de alucinógenos, tabletas, tubos de hueso, cajitas y espátulas; (b) tocados cefálicos de plumas de pájaros tropicales; (c) introducción de cultígenos como la yuca y la quínoa, y (d) semillas de Mucuna elliptica. Sin embargo, estos rasgos aparecen solo durante el último milenio del desarrollo de la tradición chinchorro (4.000-3.500 a.p.) y en una mínima representación. En el sitio Morro 1 no se registró ninguna evidencia procedente de territorios amazónicos.

Aunque la evidencia filogenética es más concluyente ahora, respecto de un flujo migratorio 
desde la Amazonia hacia la costa de Arica, de acuerdo a recientes resultados de secuenciación de ADN antiguo (Moraga et al. 2001) donde las poblaciones prehistóricas tempranas del norte de Chile tendrían una fuerte vinculación genética con poblaciones etnográficas de la cuenca amazónica. Este tipo de análisis, si bien abre importantes perspectivas respecto de la reconstrucción de los flujos migratorios desplazados por el cono sur de América, no son suficientes por sí solos para esclarecer la cuestión de los orígenes del fenómeno chinchorro.

Los actuales datos arqueológicos han dado una amplia profundidad cronológica a la tradición chinchorro, iniciada ca. 9.000 a.p. y se han constituido en importantes antecedentes para sustentar la hipótesis de un desarrollo local de las adaptaciones costeras, en cuanto a su tecnología, economía y patrón mortuorio. Esto no significa, sin embargo, negar la incorporación de elementos exóticos y selectivos de origen foráneo, ya sea como materia prima u objetos elaborados, que pudieron haber sido obtenidos vía intercambios de larga distancia, y que fueron integrados al proceso cultural y biológico de la costa desértica del norte de Chile y sur de Perú.

Agradecimientos: La autora agradece a los evaluadores de Chungara (Daniel Sandweiss, Peter Kaulicke y Lautaro Núñez), quienes hicieron sustanciales aportes para mejorar el texto. Sin embargo, en virtud que este es un trabajo eminentemente monográfico, se privilegió la detallada descripción de los contextos culturales, ya que hay una grave carencia de este tipo de datos (a excepción de la monografía del sitio Camarones 14 y la descripción de Camarones 17), lo que ha producido distorsiones en las interpretaciones culturales. Agradezco también a Mariela Santos por la elaboración de los dibujos y a Raúl Rocha por las fotografías.

\section{Referencias Citadas}

Allison, M., B. Arriaza, V. Standen, G. Focacci, M. Rivera y

J. Löwenstein

1984 Chinchorro, momias de preparación complicada: métodos de preparación. Chungara 13:155-173.

Álvarez, L.

1969 Un cementerio precerámico con momias de preparación complicada. Rehue 2:181-190.

Arriaza, B

1994 Tipología de las momias chinchorro y evolución de las prácticas de momificación. Chungara 26:11-24.

1995 Chinchorro bioarchaeology: Chronology and mummy seriation. Latin American Antiquity 6:35-55.

Arriaza, B., A. Aufderheide e I. Muñoz

1993 Análisis antropológico-físico de la inhumación de Acha 2. En: Acha 2 y los Orígenes del Poblamiento Humano en Arica, editado por I. Muñoz, B. Arriaza y A. Aufderheide, pp. 4762. Ediciones Universidad de Tarapacá, Arica.

Aufderheide, A.

1993 Reconstrucción química de la dieta del hombre de Acha. En Acha 2 y los Orígenes del Poblamiento Humano en Arica, editado por I. Muñoz, B. Arriaza y A. Aufderheide, pp. 65-80. Ediciones Universidad de Tarapacá, Arica.

1996 Secondary applications of bioanthropological studies on South American Andean mummies. En Human Mummies. A Global Survey of their Status and the Techniques of Conservation, editado por K. Spindler, pp. 141-151. Wien; New York: Spinger-Verlag.

Aufderheide, A., I. Muñoz y B. Arriaza

1993 Chinchorro mummies and the prehistory of northern Chile. American Journal of Physical Anthropology 91:189-202.
Binford, L.

1980 Willow smoke and dog's tails: Hunter and gatherer settlement systems and archaeological sites formation. American Antiquity 45:1-17.

Bird, J.

1943 Excavations in the northern Chile. En Anthropological Papers of the American Museum of Natural History Vol. 38:173-318. N.Y.

1946 The cultural sequence of north Chilean coast. En Handbook of South American Indians, editado por T.D. Steward, pp. 587-594. Bulletin 143, Vol. 2, Smithsonian Institution, Washington D.C.

Bittmann, B.

1982 Revisión del problema chinchorro. Chungara 9:46-79.

Bittmann, B. y J. Munizaga

1976 The earliest artificial mummification in the world? A study of the Chinchorro Complex in northern Chile. Folk 18:61-92.

1979 El arco en América: evidencia temprana y directa de la cultura chinchorro (norte de Chile). Indiana 5:229-251.

Cocilovo, J., H. Varela, O. Espoueys y V. Standen

2001 El proceso microevolutivo de la población nativa antigua de Arica. Chungara 33:13-20.

Chapman, A.

1988 Los Selknam. EMECE editores, Buenos Aires.

Emery, I.

1966 The Primary Structures of Fabrics. The Textile Museum, Washington DC.

Emperaire, J.

1963 Los Nómades del Mar. Ediciones Universidad de Chile, Santiago. 
Focacci, G.

1974 Excavaciones en Playa Miller 7, Arica. Chile. Chungara 3:23-4.

Focacci, G. y S. Chacón

1989 Excavaciones arqueológicas en los faldeos del morro de Arica, sitios Morro-1/6 y 2/2. Chungara 22:25-62.

Guillén, S. E.

1992 Chinchorro Culture: Mummies and Crania in the Reconstruction of Preceramic Coastal Adaptation in the South Central Andes. Doctoral dissertation, University of Michigan

Gusinde, M.

1982 Los Indios de Tierra del Fuego, Tomo I. Los Selknam. Centro Argentino de Etnología Americana, Buenos Aires.

Llagostera, A.

1989 Caza y pesca marítima (9000-1000 a.C.). En Prehistoria de Chile, editado por J. Hidalgo, V. Schiappacasse, $\mathrm{H}$. Niemeyer, C. Aldunate e I. Solimano, pp. 57-79. Editorial Andrés Bello, Santiago.

Moraga M., E. Aspillaga, C. Santoro, V. Standen, P. Carvallo y F. Rothhammer

2001 Análisis de ADN mitocondrial en momias del norte de Chile avala hipótesis de origen amazónico de poblaciones andinas. Revista Chilena de Historia Natural 74:711-726.

Munizaga, C.

1964 Nota sobre una estólica y una estatuilla antropomorfa, supuestamente vinculada al complejo precerámico de la costa de Arica (Chile). Revista Universitaria XLIX: 169-172.

Munizaga, C. y S. Martínez

1961 La colección arqueológica A. Nielsen de Iquique. Revista Chilena de Historia y Geografía 129:232-246.

Munizaga, J.

1974 Deformación craneal y momificación en Chile. Anales de Antropología 11:329-336. México.

1980 Esquema de la Antropología Física del norte de Chile. Chungara 6:124-136.

Muñoz, I. y J. Chacama

1982 Investigaciones arqueológicas en las poblaciones precerámicas de la costa de Arica. Documentos de Trabajo 2:3-97. Universidad de Tarapacá, Arica.

1993 Patrón de asentamiento y cronología de Acha 2. En Acha-2 y los Orígenes del Poblamiento Humano en Arica, editado por I. Muñoz, B. Arriaza y A. Aufderheide, pp. 21-46. Ediciones Universidad de Tarapacá, Arica.

Muñoz, I., B. Arriaza y A. Aufderheide

1993 El poblamiento chinchorro: nuevos indicadores bioantropológicos y discusión en torno a su organización social. En: Acha-2 y los Orígenes del Poblamiento Humano en Arica, editado por I. Muñoz, B. Arriaza y A. Aufderheide, pp.107-132. Ediciones Universidad de Tarapacá, Arica.

Núñez, L.

1963 En torno a los propulsores prehispánicos del norte de Chile. Boletín de la Universidad de Chile 44:4-8.

1969 Sobre los complejos culturales Chinchorro y Faldas del Morro. Rehue 2:111-142.

1983 Paleoindian and Archaic Cultural Periods in the Arid and Semiarid Regions of Northern Chile. Advances in World Archaeology 2:161-222.
1999 Archaic Adaptation on the South-Central Andean Coast. En: Pacific Latin America in Prehistory. The Evolution of Archaic and Formative Cultures, editado por Michael Blake, pp. 199-211. Washington State University Press, Washington.

Núñez, L. y C. Moragas

1977-78 Ocupación Arcaica Temprana en Tiliviche, norte de Chile, I Región. Museo Arqueológico La Serena. Boletín 16:53-76.

Núñez, L. y H. May

1982 Análisis de la dieta y movilidad en un campamento arcaico del norte de Chile. Boletín del Instituto Francés de Estudios Andinos Vol. XI, № 3:91-113.

Núñez, P.

1977-78 Actividades en la comuna de Pisagua. Museo Arqueológico La Serena, Boletín 16:42-51.

Rivera, M.

1975 Una hipótesis sobre movimientos poblacionales transaltiplánicos a las costas del norte de Chile. Chungara 5:7-31.

Rivera, M., P. Soto, L. Ulloa y D. Kushner

1974 Aspectos sobre el desarrollo tecnológico en el proceso de agriculturación en el norte prehispánico, especialmente Arica (Chile). Chungara 3:79-107.

Rivera, M. y V. Zlatar

1982 Las estólicas en el desarrollo cultural temprano prehispánico del Norte de Chile. Actas del IX Congreso Nacional de Arqueología Chilena, pp.14-34. La Serena, Chile.

Rivera, M. y F. Rothhammer

1986 Evaluación biológica y cultural de las poblaciones chinchorro. Nuevos elementos para la hipótesis de contactos transaltiplánicos: Cuenca Amazonas-Costa Pacífico. Chungara 16-17:295-306.

1991 The chinchorro people of northern Chile 5000 BC-500 $\mathrm{BC}$, a review of their culture and relationships. International Journal of Anthropology 6:243-255.

Rothhammer, F.

1989 Peopling of Andean South America. American Journal of Physical Anthropology 78:403-410.

Sahlins, M.

1983 Economía de la Edad de Piedra. Editorial Akal, Madrid.

Santoro, C. y L. Núñez

1987 Hunters of the dry puna and salt puna in the northern Chile. Andean Past 1:57-110.

Schaedel, R., A. Nielsen y A. Toro

1957 Excavación de un sepulcro cerca de Bajo Molle. En Informe General sobre la Expedición a la Zona Comprendida entre Arica y La Serena. Arqueología Chilena, editado por R. Schaedel, pp. 71-72. Centro de Estudios Antropológicos, Universidad de Chile, Santiago.

Schiappacasse, V. y H. Niemeyer

1984 Descripción y Análisis Interpretativo de un Sitio Arcaico Temprano en la Quebrada de Camarones. Publicación Ocasional 14. Museo Nacional de Historia Natural. Santiago.

Soto, P.

1974 Análisis Antropológico Físico de restos humanos correspondientes a Chinchorro, El Laucho y Alto Ramírez. Chungara 3:85-93. 
1987 Evolución de deformaciones intencionales, tocados y prácticas funerarias en la prehistoria de Arica, Chile. Chungara 19:129-214.

Standen, V.G.

1991 El Cementerio Morro 1: Nuevas Evidencias de la Tradición Funeraria Chinchorro (Período Arcaico, Norte de Chile). Tesis de Maestría en Arqueología, Universidad Católica de Lima, Perú.

1997 Temprana complejidad funeraria en la cultura chinchorro: Norte de Chile. Latin American Antiquity 8:134-156.

Standen, V. y L. Núñez

1984 Indicadores antropológico-físicos y culturales del cementerio precerámico Tiliviche-2 (norte de Chile). Chungara 12:175-185.

Standen, V.G., B.T. Arriaza y C.M. Santoro

1996 Hipótesis ambiental para un marcador óseo: La exostosis auditiva externa en las poblaciones humanas prehispánicas del desierto del norte de Chile. Chungara 27:99-116.

Standen, V.G. y C.M. Santoro

1997 Acha 3 y su relación con Chinchorro. Ponencia presentada al XIV Congreso Nacional de Arqueología Chilena. Copiapó, Chile.

Standen, V.G. y B.T. Arriaza

2000 Traumas in the preceramic coastal populations of northern Chile: Violence or occupational hazards? American Journal of Physical Anthropology 112:239-249.

\section{Sutter, R.}

1997 Dental Variation and Biocultural Affinities among Prehistoric Populations from the Coastal Valleys of Moquegua, Perú, and Azapa, Chile. Doctoral dissertation University of Missouri, Columbia.

Uhle, $M$.

1917 Los aborígenes de Arica. Museo de Etnología y Antropología 14 y 15:151-176.

1919 La arqueología de Arica y Tacna. Boletín de la Sociedad Ecuatoriana de Estudios Históricos Americanos III (7-8):1-48.

Ulloa, L.

1974 El desarrollo textil de los sitios chinchorro, El Laucho y Alto Ramírez, Arica. Chungara 3:79-107.

Vilaxa, A. y J. Corrales

1993 Descripción y comentario de la fauna malacológica de sitio Acha 2. En: Acha-2 y los Orígenes del Poblamiento Humano en Arica, editado por I. Muñoz, B. Arriaza y A. Aufderheide, pp. 81-89. Ediciones Universidad de Tarapacá, Arica.

Wise, K.

1995 La ocupación Chinchorro en Villa del Mar, Ilo, Perú. Gaceta Arqueológica Andina 24:135-149.

\section{Notas}

1 En un primer trabajo se consideraron 96 individuos (Allison et al. 1984). Una reevaluación de la colección Morro 1 y posteriores rescates ha aumentado a 134 el número de individuos analizados, aunque no todos los registros están completos, por la gran perturbación y erosión que presenta en su conjunto el Morro de Arica.

2 Los fechados presentados no están sometidos al factor de corrección, en años calendáricos. Bernardo Arriaza (comu- nicación personal) prepara un manuscrito enfocado al problema cronológico sustentado en 30 dataciones de radiocarbono sometidas a calibración y corrección, próximo a ser publicado.

3 En un trabajo previo (Standen 1991) fueron definidas dos fases cronológicas para el sitio Morro 1. Sin embargo, por el amplio rango de los fechados de radiocarbono $\mathrm{C} 14$ se definieron tres fases. 
